\title{
LARGE LEARNING GAINS IN POCKETS OF EXTREME POVERTY: EXPERIMENTAL EVIDENCE FROM GUINEA BISSAU
}

\author{
Ila Fazzio \\ Alex Eble \\ Robin L. Lumsdaine \\ Peter Boone \\ Baboucarr Bouy \\ Pei-Tseng Jenny Hsieh \\ Chitra Jayanty \\ Simon Johnson \\ Ana Filipa Silva \\ Working Paper 27799 \\ http://www.nber.org/papers/w27799
}

\author{
NATIONAL BUREAU OF ECONOMIC RESEARCH \\ 1050 Massachusetts Avenue \\ Cambridge, MA 02138 \\ September 2020, Revised February 2021
}

Fazzio and Eble share "co-first author" status, as they contributed equally to the work (order of co-first author names was randomized according to Ray and Robson 2018).We are grateful to our administrative, research, and implementation teams in Bissau for their tireless work. Ana Forjaz oversaw the fieldwork at endline. Mark Fisher designed and maintained the database. Gilda Piaggio conducted the power calculation and randomization at the beginning of the study. Yixun Zeng provided research assistance in the preliminary stages of the data analysis. Clive Belfield and Sharon Wolf gave helpful comments on the manuscript. We are grateful to the National Bureau of Economic Research (NBER) for funding the exploratory research on learning levels in Guinea Bissau that motivated this study. We thank the editor and two anonymous referees for generous input which greatly improved the work. This study was funded by Effective Intervention, a UK registered charity. The study passed ethical/ institutional review by the Ministry of Education of Guinea Bissau on 30 August, 2012, and the NBER ethics committee on 1 July, 2014 (ref: IRB Ref\#14_06). The views expressed herein are those of the authors and do not necessarily reflect the views of the National Bureau of Economic Research.

NBER working papers are circulated for discussion and comment purposes. They have not been peer-reviewed or been subject to the review by the NBER Board of Directors that accompanies official NBER publications.

(C) 2020 by Ila Fazzio, Alex Eble, Robin L. Lumsdaine, Peter Boone, Baboucarr Bouy, Pei-Tseng Jenny Hsieh, Chitra Jayanty, Simon Johnson, and Ana Filipa Silva. All rights reserved. Short sections of text, not to exceed two paragraphs, may be quoted without explicit permission provided that full credit, including $(\odot)$ notice, is given to the source. 
Large Learning Gains in Pockets of Extreme Poverty: Experimental Evidence from Guinea

Bissau

Ila Fazzio, Alex Eble, Robin L. Lumsdaine, Peter Boone, Baboucarr Bouy, Pei-Tseng Jenny

Hsieh, Chitra Jayanty, Simon Johnson, and Ana Filipa Silva

NBER Working Paper No. 27799

September 2020, Revised February 2021

JEL No. I21,I24,I25,J24,O15

\section{ABSTRACT}

Children in many extremely poor, remote regions are growing up illiterate and innumerate despite high reported school enrollment ratios. Possible explanations for such poor outcomes include demand - for example, low perceived returns to education compared to opportunity cost; and supply - poor state provision and inability of parents to coordinate and finance better schooling. We conducted a cluster-randomized trial in rural Guinea Bissau to understand the effectiveness and cost of concerted supply-based interventions in such contexts. Our intervention created simple schools offering four years of education to primary-school aged children in lieu of the government. At endline, children receiving the intervention scored 58.1 percentage points better than controls on early grade reading and math tests, demonstrating that the intervention taught children to read and perform basic arithmetic, from a counterfactual condition of very high illiteracy. Our results provide evidence that particularly needy areas may require more concerted, dramatic interventions in education than those usually considered, but that such interventions hold great potential for increasing education levels among the world's poorest people.

\author{
Ila Fazzio \\ Effective Intervention \\ Madrid, Spain \\ if@effint.org \\ Alex Eble \\ Department of Education Policy \\ and Social Analysis \\ Teachers College \\ Columbia University \\ 525 W 120th St \\ New York, New 10027 \\ eble@tc.columbia.edu \\ Robin L. Lumsdaine \\ Kogod School of Business \\ American University \\ 4400 Massachusetts Avenue NW \\ Washington, DC 20016 \\ and NBER \\ robin.lumsdaine@american.edu
}

\author{
Peter Boone \\ London School of Economics \\ pb@effint.org \\ Baboucarr Bouy \\ Effective Intervention \\ Kerr Serign \\ Gambia \\ bbouy@effint.net \\ Pei-Tseng Jenny Hsieh \\ Oxford University \\ Oxford \\ United Kingdom \\ ptjhsieh@gmail.com \\ Chitra Jayanty \\ Hyderabad \\ India \\ chitra.jayanty@gmail.com
}


Simon Johnson

MIT Sloan School of Management

100 Main Street, E52-562

Cambridge, MA 02142

and NBER

sjohnson@mit.edu

Ana Filipa Silva

Effective Intervention

Bissau, Guinea-Bissau

filipa.n.r.silva@gmail.com

A randomized controlled trials registry entry is available:

https://www.socialscienceregistry.org/trials/3670 


\section{Introduction}

Children in many extremely poor, remote regions are growing up illiterate and innumerate despite high reported school enrolment ratios (Glewwe and Muralidharan 2016). This "schooling without learning" has many alleged sources, such as insufficient demand for schooling, inadequate schooling materials, and lack of qualified, motivated teachers (Kremer, Brannen, and Glennerster 2013; Pritchett 2013). This leads to at least three important social phenomena: one, a substantial part of the population being illiterate and innumerate; two, for these children, lower lifetime incomes as a result, and less opportunity to succeed in the growing worlds around them; and three, potentially greater socioeconomic inequality between these children and children in areas which receive better schooling.

In this article, we report the results of a cluster-randomized controlled trial (RCT) evaluating a supply-based intervention which aims to dramatically increase learning levels in particularly poor, rural areas of the developing world. The intervention provides the early years of primary school in lieu of the government; this entails hiring, training, and monitoring teachers tasked with delivering schooling, from the pre-primary level on to grade 3 , to primary-aged children. The intervention uses a bespoke curriculum which includes teacher training materials and teaching and learning materials for both teachers and students. It also employs frequent monitoring and assessment of teachers and children and regular community outreach / involvement. We conducted this RCT in rural areas of Guinea Bissau, one of the poorest and most troubled countries on the planet (da Silva and Oliveira 2017).

The intervention yielded transformative learning gains among children who would otherwise be unlikely to ever achieve literacy and numeracy. After four years of receiving the intervention, children in the intervention group scored 58 percentage points better than children 
in the control group on a composite score of tests of mathematics and reading ability. This difference comprises large gains in both math and reading ability across the difficulty spectrum, from letter and number recognition to reading comprehension and two-digit subtraction with borrowing. A very high proportion of control children had zero scores on these tests. Using the test's definition of literacy, 63 percent of intervention children demonstrate literacy at endline, compared to less than 0.1 percent of control children. Unfortunately, there is no consensus on how to measure numeracy in these tests. Instead, we report two results. Using a benchmark from Ghana $^{1}, 21.3$ percent of intervention children demonstrate numeracy at endline while no control children do. Using a measure of more basic numeracy, 73.2 percent of intervention children display basic numerical skills, while less than 0.1 percent of control children do.

These gains are dramatic in absolute as well as relative terms, with intervention children from rural Guinea Bissau exhibiting literacy and numeracy skills similar to children in much wealthier countries with functioning school systems. A commonly-used metric for measuring reading skill among early grade children is oral reading fluency (ORF), measured by the correct number of words read per minute from a set passage. Endline ORF of children randomized to receive the intervention was 75 correct words per minute. This compares favorably to the ORF measured in a 2014 national assessment of third grade students in the Philippines and is similar to that of the (much wealthier) Latin American countries who have used similar tests. ${ }^{2}$

Our approach has important common traits with the influential studies of ambitious, highly-resourced interventions in the US designed to address inequality and raise outcomes for the less fortunate. The most famous of these are the Perry Pre-school and Abecedarian programs

\footnotetext{
${ }^{1}$ Described in Section 4.

${ }^{2}$ Philippines: https://earlygradereadingbarometer.org/overview, accessed on October 28, 2019. Latin America: the average grade three ORF is 73 words per minute in English, and 79 in Spanish according to USAID (2019).
} 
(Campbell and Ramey 1994; 1995; Heckman, Pinto, and Savelyev 2013). There are three main similarities: first, these programs targeted needy or at-risk children. Second, they provided a suite of services, including a comprehensive educational intervention which comprised well-trained and well-supervised teachers, a structured curriculum, and family outreach. Finally, similar to our program, those programs were also relatively expensive, but demonstrated a positive return on investment above that of equity (Heckman et al. 2010). Overall, we argue that our study provides proof of concept that a resource-intensive intervention can generate large gains in a challenging setting, but perhaps with a model that might be difficult to scale or replicate. This is reflected in other work which documents that achieving scalable impacts in education is difficult, especially among highly effective interventions (Banerjee et al. 2017; Bold et al. 2018).

Our approach also parallels research on the efficacy of charter schools and "model schools" in the US (Angrist, Pathak, and Walters 2013; Dobbie and Fryer Jr 2013). These studies show that new, non-governmental schools which combine a suite of teaching practices and other components known to be effective can substantially improve learning, relative to traditional public schools. Furthermore, gains are largest in contexts, similar to ours, where the status quo option is of particularly low quality (Chabrier, Cohodes, and Oreopoulos 2016).

Our findings contribute to ongoing efforts to identify effective means to increase learning levels, and welfare more generally, in the poorest parts of the world (McEwan 2015; Glewwe and Muralidharan 2016). A growing set of studies shows the potential for targeted interventions to achieve large gains in settings with low learning levels (c.f., Burde and Linden 2012; Muralidharan, Singh, and Ganimian 2019). We advance this work by showing the success of a concerted supply-based intervention -which delivered all aspects of early primary education instead of the government - in achieving these goals in a particularly challenging setting. Our 
approach mirrors the use of "bundled" interventions to tackle otherwise intractable problems, such as extreme poverty (Banerjee et al. 2015).

The rest of our paper proceeds as follows. Section 2 describes the context we work in, the challenges we encountered in initial implementation, and the final intervention design. Section 3 describes our research design. Section 4 presents our main results. Section 5 discusses our results in the context of other studies of education in disadvantaged areas and Section 6 concludes.

\section{Background and intervention details}

In this section, we describe the context in which the study took place, the initial challenges faced in early attempts to implement the intervention, and the final intervention we study.

\subsection{Context}

Guinea Bissau is a Lusophone country in West Africa with a population of approximately 1.8 million people. Once a Portuguese colony, it attained independence in 1974. Since then, it has been beset by political and economic troubles. There have been four coups d'etat since its founding. Until 2018, there had been no elected president who had completed a full five-year term. It is one of the poorest countries in the world both on per-capita GDP terms and according to the UN's Human Development Index (da Silva and Oliveira 2017). ${ }^{3}$ Aside from some parts of the capital, there is no national power or water grid. The official language of the country is Portuguese but the dominant language is Crioulo - a hybrid of Portuguese and several local tongues - which is spoken as a first or second language by the majority of the population.

\footnotetext{
${ }^{3}$ The economy is largely dependent on agriculture, primarily cashews. Because of its geographic location and low state capacity, Guinea Bissau has been used as a way station for the transportation of cocaine to Europe, adding to corruption and governance issues (da Silva and Oliveira 2017).
} 
In Figure A.1 we show a map of the country and our study areas. Our study took place in villages in the Quinara and Tombali regions in the southwest of the country. These regions were selected for two reasons: first, the government requested that we work in the two regions as they were less well-served by existing NGO work; second, Boone et al. (2014) identified them as the regions with the lowest learning levels in the country.

\subsection{Education, literacy, and numeracy in Guinea Bissau}

Guinea Bissau's official education system comprises three levels: nine years of compulsory, basic education (four years of lower primary, called the "first cycle"; two years of upper primary, or second cycle; and three years of middle school, or third cycle), followed by three years of elective secondary school and then higher education. The official ages for primary school are currently 6 to $12 .{ }^{4}$ As in many developing countries, the age at which children actually enter school varies widely.

Boone et al. (2014) report the results of a nationally representative survey of schools, families, and children across Guinea Bissau in 2010..$^{5}$ They found very low education levels among parents: among fathers, approximately 40 percent had ever been to school, and 24 percent were able to read a printed paragraph. Among mothers, only nine percent had ever been to school, and 2.8 percent were able to read the same paragraph. Among children, however, the survey found substantial enrolment in school: approximately 85 percent of interviewed children between the ages of 7 and 17 had been to school, and 70 percent were currently enrolled. Unfortunately, these high enrolments did not translate to learning. Fewer than one third of these children could recognize a single digit number or read a single, simple Portuguese word.

\footnotetext{
4 They were 7 to 13 at the start of our trial.

${ }^{5}$ Excluding the islands of Bolama and Bilagós.
} 
Parents recognized the low quality of the education their children were getting, and expressed demand for higher quality schools. Of the over 8,500 parents and caregivers interviewed, more than 98 percent asserted that they would be willing to pay, on average, approximately 20 percent of household income per school-aged child, for better schooling for the child. The authors of that study conclude that there is probably substantial demand in rural Guinea Bissau for quality schooling, but some combination of income, credit market failures, capacity, and collective action constraints impede its provision. Even so, the extremely poor educational outcomes in these regions - regardless of the type of schools - suggests that either demand or supply could be the key reason that children grow up mostly illiterate and innumerate. These findings motivated the current study.

\subsection{Status quo provision of education in study area}

Guinea Bissau is often considered a "failed state" because of its frequent coups, highly irregular payment of its civil servants, and the absence of many basic government services. Education is one such service, and the reach of government schools in most areas, including our study area, is uneven and erratic. At baseline, only half of schools in our trial area were run by the government, with the rest run by either the local community (35\%) or an NGO or other private organization (15\%). Ostensibly, children are meant to attend school for four hours per day, five days per week, nine months out of the year. In practice, government schools were open less frequently in our study area because of teacher strikes in these schools; according to official data, strikes disrupted roughly $25 \%$ of school days for government schools during our study. Not all official strikes made their way to our rural areas, however, and roughly half of the schools in the control area were not run by the government and so were not affected. 
While statistical data from the government and other sources is sparse, Boone et al. (2014) also provide a thorough description of the "status quo" of education provision in rural Guinea Bissau. The study visited schools to collect data on teachers (presence and demographic data), as well as infrastructure data from a representative sample of 351 schools and 781 teachers. The authors found that 86 percent of visited schools were open, with teachers present and teaching, and 72 percent of enrolled children were present when the schools were visited. ${ }^{6}$ These schools all had chalkboards and roughly one textbook for every 30 children. The average pupil:teacher ratio (for combined grades $1-4$, as many schools have combined classrooms) was 63.4, with a high standard deviation (24.4). Boone et al. (2014) found very low correlation between either teacher qualifications or school resources and child learning levels, corroborating prior research (Lepri 1988; Daun 1997).

Overall, these areas are characterized by extremely low learning levels despite the fact that, barring strikes, schools are usually open and teacher and student absenteeism is relatively low. Although Boone et al. (2014) set out to find examples of success in these areas, it found no such examples. A main conclusion of their paper, which also motivated this study, is that in Guinea Bissau "the public sector cannot be relied on to provide regular services due to political instability, institutional capacity, and a political system that does not serve the very poor."

\subsection{Intervention design}

Initially, we recruited a group of nearly 50 prospective "untrained" teachers to deliver the intervention and trained them for one year. ${ }^{7}$ At the end of this year of training, the trainees

\footnotetext{
${ }^{6}$ This level of teacher absenteeism is less severe than found in Uganda in Chaudhury et al. (2006) and at the lower end of the range of what Blimpo, Evans, and Lahire (2011) observe in Gambia.

${ }^{7}$ Originally this study was part of a larger effort to study the generalizability of a para teacher intervention in India (Lakshminarayana et al. 2013), run in tandem with a similar effort in The Gambia (Eble et al. 2021)
} 
reneged on their commitments to us, demanding a dramatic change in the agreed-upon employment conditions - including a salary increase to a level equivalent to that of the education ministry's director-general - and sued us in the country's courts. While the government sided with us and these individuals' suit was determined to be without merit, we were forced to postpone the study until the court case was resolved. The case was ultimately resolved in our favor, but resulted in our loss of all 48 selected candidates. In Appendix A, we explain this experience in greater detail.

We then had to begin the search for - and training of - candidates anew, and we decided to hire certified teachers instead of untrained ones. The logic behind this decision was twofold: one, these teachers required less training and so the extra training we gave them would be less likely to cause them to demand dramatically higher compensation; two, it would allow us to start the intervention more promptly. Using this strategy, we were able to identify fewer willing and suitable candidates; we describe the impact of this on our study design in the next section.

In villages randomly selected to receive the intervention, we provided four years of school - first, a year of pre-primary school focusing on Portuguese language acquisition, then grades 1-3 of the national primary education curriculum. This schooling was meant to take the place of official instruction in these years usually delivered by Guinea Bissau's government educational system. We included the year of pre-primary because the national curriculum is in Portuguese. To the best of our knowledge, only a trivially small number of children in our study area had any knowledge of the language at the time of school entry.

We aimed to have 25 to 30 students per class, resulting in a total of 24 academic classes across the 16 intervention villages in our study. Classes were held in spaces provided and 
furnished by each community. ${ }^{8}$ The curriculum of these classes was designed to maximize child participation throughout the day. The overall intervention strategy was inspired by the experience, design, tools, and teaching methods of an early primary school intervention designed by the Naandi Foundation and evaluated in a prior RCT in India (Lakshminarayana et al. 2013). ${ }^{9}$ Final instructional tools were developed in consultation and with review by the ministry of education in Guinea Bissau, covering the content in the official Guinea Bissau primary curriculum. These tools included daily lesson plans, a teacher handbook, child workbooks, and other grade-specific didactic materials.

Teachers were recruited with the requirement that they be able to speak and teach in the local language spoken in the community in which they were assigned to work. Once hired, they received two types of training: first, 10 weeks of initial pre-service training in how to implement our intervention; second, four weeks of in-service training conducted annually before the beginning of each new academic year to prepare teachers to teach the next year's content. ${ }^{10} \mathrm{In}$ each village, the intervention also hired a local adult for the first four months who spoke the most prominent local language. This person assisted the teacher with classroom management and the children's transition from use of their mother tongue to Portuguese.

Teachers conducted classes for five hours per day, five days a week, plus additional hours when required by the curriculum plan or teachers' assessments of child learning needs, for nine

\footnotetext{
${ }^{8}$ This request for support from the community was intended to promote community backing of the intervention and to increase parent involvement in the formal education of their children and the management of the academic classes.

${ }^{9}$ This study, along with the study reported in Eble et al. (2021), were a part of larger efforts to attempt to replicate the success of Lakshminarayana et al. (2013) in newer, more challenging contexts. In Eble et al. (2021), which took place in The Gambia, the authors used the after-school supplementary lesson design of the intervention studied in Lakshminarayana et al (2013). In Guinea Bissau, we shifted our strategy to providing regular schooling, instead of the state, in light of the history of frequent, prolonged disruptions to state-provided education.

${ }^{10}$ These trainings emphasized the use of relevant, grade-appropriate teaching strategies as well as use of the intervention's bespoke teaching and learning materials.
} 
months each year. The duration of the intervention spanned February 2014 to December 2017, comprising 730 school days in total. Teachers were paid salaries of 200,000 Central African Francs (or CFA; roughly, US \$345) per month, with an additional per-diem to compensate them for the difficulty of living in the villages in which they worked (1,500 CFA, or US $\$ 2.59$, per day). ${ }^{11}$

The intervention team monitored both teachers' work and children's learning in order to track progress and ensure that learning was progressing as planned. Monitors - a separate cadre of staff recruited by the intervention arm - visited each academic class for two days each month. The team conducted monthly, two-day review meetings for teachers and monitors. In these meetings, teachers received feedback and training based on the evidence collected during that month's classroom observations/monitoring. These meetings were also used to reinforce the intervention's main methodology and teaching strategies, focusing on concrete examples of what to do, how to do it, and what not to do. Each month, the intervention team assessed some children on the curriculum in their current grade, and conducted larger-scale evaluations of child learning every six months.

Implementing this intervention was intensely challenging. We chose to work in small, isolated villages; the rugged terrain, long distances between villages, and poor state of the roads between them made frequent, spontaneous monitoring difficult, particularly during the rainy season when some villages become inaccessible. These villages lacked internet connections and reading materials, and had few or no literate residents who might reinforce child learning. This also made it difficult to recruit qualified teachers, who were required to reside in the village. ${ }^{12}$

\footnotetext{
${ }^{11}$ This was raised midway through the trial to be a 250,000 salary and 2,500 per diem, respectively.

${ }^{12}$ Although recruitment of teachers was difficult, once recruited, all teachers remained in the project until its completion.
} 
Further complicating literacy efforts, multiple languages are spoken in these regions, none of which have their own script. Finally, none of the parents enumerated were native speakers of Portuguese, the official language of the curriculum and of the intervention; this also restricted children's ability to practice and apply the lessons from class outside of school.

\section{Research design}

This section describes our research design, including the study population, our sample size/power calculations, the nature of the data collected, and the pre-specified (relative to unblinding of the data) analysis plan.

\subsection{Study design}

In the first screening of villages for eligibility, we began with all four hundred and thirty-nine villages in the Quinara and Tombali regions with between 50 and 400 households according to the Guinea Bissau National Institute of the Census. ${ }^{13}$ We used existing map information and Quantum GIS (version 1.7.2) to select villages that were at least nine kilometers apart from each other to avoid risks of spillover from one village to another. With this method we pre-selected 49 villages for enumeration, along with a set of backups should there be need for replacement.

We then conducted field visits to record the GPS points of these villages and confirm whether they met the following three eligibility criteria for inclusion in our study: i) the village had between 50 and 400 households; ii) the village was reachable by land during the country's dry season; and iii) the village had no other NGO-administered education program taking place. Within these villages, our eligibility criteria for enrolling children in the study were that: i) the child was born between January 2007 and September 2008; ii) the child was resident in an

\footnotetext{
${ }^{13}$ In this initial screening we also included villages for which information on the number of households was missing.
} 
eligible village; iii) the child did not have any serious physical or mental conditions that may have impaired learning, i.e., severe developmental handicaps; and iv) the child's parents gave consent to participate in the study.

We further restricted eligibility to villages which had at least 20 eligible children. After the initial village visits to confirm eligibility, four of the 49 pre-selected villages had fewer than 20 eligible children and therefore were not included; these villages were replaced with other villages from the list of backups. We then enrolled these final 49 villages, containing a total of 2,112 eligible children, for participation in our study. ${ }^{14}$ Given the teacher recruitment challenges noted in the previous section, we switched from a 1:1 control:intervention cluster ratio to a 2:1 ratio to ensure that we only worked in as many villages as we could find qualified teachers for. Our final sample comprised 16 intervention villages and 33 control villages.

We conducted randomization by computer, stratifying at the village level based on a composite variable comprising a weighted average of several indicators: the village's distance to the nearest road, the highest grade taught by the local school (in the one case where the village did not have a school, we set this to zero), the number of households in the village, the proportion of mothers speaking Crioulo in the village, and the third quartile of mothers' educational attainment in the village. We selected these variables on the assumption that they would be correlated with the primary outcome, as shown in Boone et al. (2014). The results of our cluster analysis suggested that randomizing within two strata was sufficient. ${ }^{15}$ This led to the generation of one stratum with 32 villages, in which villages were randomized 2:1 to control and intervention status, and another stratum with 17 villages and the same randomization profile.

\footnotetext{
${ }^{14}$ While the sample size is smaller than we initially planned, it is consistent with or somewhat larger than the sample size of studies of other hard-to-reach populations, e.g., Burde and Linden's (2012) study of community schools in Afghanistan.

15 The cluster analysis was conducted in SAS Software version 9.3, using the command "PROC CLUSTER."
} 
From December 2012 to April 2013, we conducted our baseline enumeration for the purposes of enrolling children into the study. The mean number of enumerated children per village was 43 . To conduct our sample size calculation, we took attrition figures from a study of child health in the country, which suggested roughly $17 \%$ loss to follow-up over the course of the study (Mann et al. 2009). Using this, we expected an average of 35 children per village to be present for the endline test, and thus contribute to the primary outcome.

This led to the following power calculation, conducted before commencing randomization: a study population of 49 villages, with an average of 35 eligible children per village and a 2:1 control:intervention randomization ratio, provides $92 \%$ power to detect a difference in test scores of at least $0.25 \mathrm{SD}$ in a two-sided test with a five percent significance level, assuming an intra-cluster coefficient of 0.03. In Appendix Table A.1 we show similar calculations for different scenarios (greater loss to follow-up and a 1:1 control:intervention ratio). We registered our statistical pre-analysis plan (also known as an SAP or PAP) at www.socialscienceregistry.com prior to unblinding of the data. ${ }^{16}$

While the study was unblinded to participants - it was impossible to prevent parents from knowing whether or not they were in a village that was receiving materials and teaching support - the research team that conducted the surveys and tested the children were not given information on which villages were in each arm. Furthermore, these staff were closely monitored to ensure that data collection procedures were consistent across all villages.

In Tables 1 and 2, we provide summary statistics at the village and child level, respectively, showing characteristics separately by whether the village/child is in the intervention or control group. Relative to intervention villages, control villages tended to be slightly more

${ }^{16}$ RCT ID: AEARCTR-0003670. 
remote and larger in population. For the most part, children in the intervention and control arms were quite similar. At the bottom of each table, we conduct a test for the joint significance of these characteristics in predicting randomization status, as in Bruhn and McKenzie (2009).

Table 1. Baseline cluster characteristics

\begin{tabular}{|c|c|c|c|}
\hline Variable & $\begin{array}{c}\text { (1) } \\
\text { Intervention } \\
\end{array}$ & $\begin{array}{c}\text { (2) } \\
\text { Control } \\
\end{array}$ & $\begin{array}{c}(3) \\
\text { Difference }\end{array}$ \\
\hline $\begin{array}{l}\text { Overall distance to a main road }{ }^{*} \text { in } \mathrm{km} \\
\text { (distance }=0 \text { if village has a road) }\end{array}$ & 7.88 & 8.52 & -0.64 \\
\hline Randomized children: mean (SD) & $\begin{array}{c}40.56 \\
(19.12)\end{array}$ & $\begin{array}{c}44.33 \\
(23.59)\end{array}$ & 3.77 \\
\hline \multicolumn{4}{|l|}{ Predominant ethnic group } \\
\hline Balanta & $25 \%(4)$ & $51.5 \%(17)$ & $-21.5 \%$ \\
\hline Fula & $25 \%(4)$ & $15.2 \%(5)$ & $9.8 \%$ \\
\hline Beafada & $25 \%(4)$ & $24.2 \%(8)$ & $0.8 \%$ \\
\hline Other & $25 \%(4)$ & $9.1 \%(3)$ & $15.9 \%$ \\
\hline $\begin{array}{l}\text { Cluster size (number of households): } \\
\text { mean (SD) }\end{array}$ & $\begin{array}{l}117.31 \\
(47.36)\end{array}$ & $\begin{array}{l}128.85 \\
(74.59)\end{array}$ & 11.54 \\
\hline Number of villages & 16 & 33 & -- \\
\hline $\begin{array}{l}\text { F-statistic for test of joint significance } \\
\text { (p-value) }\end{array}$ & -- & -- & $\begin{array}{c}1.51 \\
(0.199)\end{array}$ \\
\hline
\end{tabular}

Table 1 notes: this table shows baseline characteristics for the villages in our trial, separately by treatment group and the raw difference between these values. ${ }^{*}$ : Main road is defined as a road that is connected to at least one periurban or urban area via regular public transport.

\subsection{Primary outcome and analysis methods}

The pre-specified primary outcome of our study is the child's "composite score." This is the arithmetic mean of the child's scores on EGRA an EGMA tests, administered sequentially, to each enrolled child present in the village at time of testing in November and December of 
Table 2. Baseline child characteristics

\begin{tabular}{|c|c|c|c|}
\hline Variable & $\begin{array}{c}\text { (1) } \\
\text { Intervention } \\
\end{array}$ & $\begin{array}{c}(2) \\
\text { Control } \\
\end{array}$ & $\begin{array}{c}(3) \\
\text { Difference } \\
\end{array}$ \\
\hline Child is female & $49.15 \%(319)$ & $48.60 \%(711)$ & $0.55 \%$ \\
\hline \multicolumn{4}{|c|}{ Identity of the interviewed caregiver for the child } \\
\hline Mother & $49.77 \%(323)$ & $51.26 \%(750)$ & $-1.49 \%$ \\
\hline Father & $16.02 \%(104)$ & $18.87 \%$ (276) & $-2.85 \%$ \\
\hline Grandmother & $10.32 \%(67)$ & $10.39 \%(152)$ & $-0.07 \%$ \\
\hline Grandfather & $2.00 \%(13)$ & $0.96 \%(14)$ & $1.04 \%$ \\
\hline Aunt & $11.71 \%(76)$ & $7.52 \%(110)$ & $4.19 \%$ \\
\hline Uncle & $3.39 \%(22)$ & $4.03 \%(59)$ & $-0.64 \%$ \\
\hline Other & $6.78 \%(44)$ & $6.97 \%(102)$ & $-0.19 \%$ \\
\hline \multicolumn{4}{|l|}{ Mother's education } \\
\hline No education & $66.10 \%(429)$ & $71.16 \%(1,041)$ & $-5.06 \%$ \\
\hline Grades 1 to 4 & $22.96 \%(149)$ & $18.80 \%(275)$ & $4.16 \%$ \\
\hline Grades 5 to 10 & $7.86 \%(51)$ & $4.99 \%(73)$ & $2.87 \%$ \\
\hline Grades $11+$ & $0.31 \%(2)$ & $0.48 \%(7)$ & $-0.17 \%$ \\
\hline Don't know & $2.62 \%(17)$ & $4.31 \%(63)$ & $-1.69 \%$ \\
\hline \multicolumn{4}{|l|}{ Father's education } \\
\hline No education & $28.35 \%(184)$ & $30.69 \%$ (449) & $-2.34 \%$ \\
\hline Grades 1 to 4 & $16.18 \%(105)$ & $19.62 \%(287)$ & $-3.34 \%$ \\
\hline Grades 5 to 10 & $18.95 \%(123)$ & $17.02 \%$ (249) & $1.93 \%$ \\
\hline Grades $11+$ & $4.01 \%(26)$ & $2.12 \%(31)$ & $1.89 \%$ \\
\hline Don't know & $29.28 \%(190)$ & $29.12 \%(426)$ & $0.17 \%$ \\
\hline Child's age at baseline (SD)* & $4.81(0.58)$ & $4.76(0.58)$ & 0.05 \\
\hline Number of observations & 649 & 1463 & -- \\
\hline $\begin{array}{l}\text { F-statistic for test of joint } \\
\text { significance ( } p \text {-value) }\end{array}$ & -- & -- & $\begin{array}{c}1.15 \\
(0.334)\end{array}$ \\
\hline
\end{tabular}

Table 2 notes: this table shows baseline characteristics (percent, with corresponding number in parentheses) for the children in the villages in our trial, separately by treatment group, and the raw difference between these values. For age at baseline, mean age is reported (within treatment group standard deviation in parentheses). For mother's education, one observation is missing from the intervention and four from the controls. *: Due to the paucity of official birth or health records, we only have precise child age for 200 intervention children and 332 control children. To calculate the F-statistic, we replace missing age values with an arbitrary number not equal to any observed value and add a dummy for missing age.

2017. ${ }^{17}$ EGRA and EGMA tests assess early grade reading and math ability, respectively (Platas

et al. 2014; Dubeck and Gove 2015). They are administered orally, one-on-one between

\footnotetext{
${ }^{17}$ Our aggregation of EGRA and EGMA tests into a composite score was chosen for simplicity as a single primary outcome, and for consistency with related work on delivering educational interventions to other deprived areas (Lakshminarayana et al. 2013; McEwan 2015; Evans and Popova 2016; Eble et al. 2021). We note that this method of aggregation is a departure from conventional use of EGRA and EGMA scores.
} 
instructor and child. We chose them to serve as our primary outcome because they are particularly sensitive in measuring small differences in ability among children who have very low levels of learning, such as those in many parts of our trial area. Each test paper has several different subtasks, evaluating a different skill or competency. In Table A.2, we describe the nature of each subtask (the full test papers we used are given in Appendix B). In line with other work using EGRA and EGMA tests, we also present individual test scores, subtask scores, zero scores, and fluency measures (Platas et al. 2014; Dubeck and Gove 2015).

For our primary analysis, we use a linear regression to estimate the child-level difference between intervention and control groups in the primary outcome, controlling for the stratification factor used in the randomization and nothing else. In all analyses we report robust standard errors, clustering at the village level. Secondary analyses extend this model to (separately) investigate interactions by a series of prespecified subgroups. For secondary outcomes that are continuous, we also use a linear model. For those that are dichotomous (such as whether the child was enrolled in school), we show both "adjusted" differences from a linear probability model (i.e., the estimated coefficient for the intervention variable from the regression) and odds ratios from our (pre-specified) logit model. To account for bias from potential differential attrition between groups, we calculate Lee bounds (Lee 2009) for our primary outcome and the individual EGRA and EGMA scores.

\subsection{Attrition and adherence}

We next describe the flow of participants through the trial. Table 3 presents data on whether enrolled children were present in their village at the trial's midline survey and again at the endline survey. We observe roughly 13 percent attrition at midline (in the 2014/15 school year), and roughly 20 percent attrition at endline, with greater attrition from the control arm than from 
the intervention arm. We show the broader flow via a CONSORT-style diagram, in Figure A.2

(M. K. Campbell et al. 2012). We also present data on how frequently children assigned to the intervention attended the intervention classes in Table A.3. The average of all intervention children's attendance in intervention classes is above $80 \%$, and about nine percent of intervention children attended no intervention classes.

Table 3. Children resident in study village (migration)

\begin{tabular}{lcccc}
\hline \hline Year residence measured & $\begin{array}{c}(\mathbf{1}) \\
\text { Intervention }\end{array}$ & $\begin{array}{c}(\mathbf{2}) \\
\text { Control }\end{array}$ & $\begin{array}{c}(\mathbf{3}) \\
\text { Adjusted } \\
\text { Difference }\end{array}$ & $\begin{array}{c}\text { (4) } \\
\text { p-value }\end{array}$ \\
\hline Midline (late 2014/early 2015) & $89.04 \%$ & $84.95 \%$ & $4.51 \%$ & 0.025 \\
N: I=648; C=1,462 & $(577)$ & $(1,242)$ & $(1.94)$ & \\
& $87.77 \%$ & $75.19 \%$ & $12.53 \%$ & $<0.001$ \\
Endline (early 2017) & $(567)$ & $(1,094)$ & $(2.24)$ & \\
N: I=646, C=1,455 & & & & \\
\hline \hline
\end{tabular}

Table 3 notes: columns 1 and 2 show the group-specific proportion of children whom we observed at the time of a midline survey in late 2014/early 2015, and at the endline survey in early 2017, respectively (number of observations shown in parentheses below). Column 3 shows the "adjusted" difference estimated using our main estimating equation (i.e., the coefficient on the intervention variable in the linear regression described in the previous section), with standard errors, clustered at the village level, below in parentheses. Column 4 shows the pvalue of a test of the null that the adjusted difference is zero.

\section{Main results}

In this section, we present our pre-specified empirical analyses describing the main results of our study. We begin with the primary outcome - the composite test score - and then present comparisons by test (reading or math) and subtasks within each test. We then analyze heterogeneity in these results, the intervention's impact on enrollment in school and attendance, and spillover effects to the child's siblings.

\subsection{Primary outcome}

We show our primary outcome, alongside the secondary outcomes for overall math and reading scores, in Table 4, Panel A. We observe a very large difference in composite test scores between 
children in the control and intervention arms at the end of our study. The control child mean score was $11.2 \%$; for intervention children, this mean is $70.5 \%$, or a 58.1 percentage point adjusted difference. ${ }^{18}$ A common learning metric in similar studies is to use the standard deviation of the control group as a scale factor. In our setting, this is uninformative given the extremely low learning levels of the control group. ${ }^{19}$ We show the distribution of test scores of the two groups in Figure 1. Decomposing the composite score into its reading and math components, we observe large differences in both tests, although they are larger in reading (6.8\% correct vs. $72.5 \%)$ than in math $(15.6 \%$ correct vs. $68.5 \%)$. All differences are statistically significant $(\mathrm{p}<.001)$. To bound the potential impact of differential attrition on our primary outcome estimates, we calculate Lee bounds and show them in column 5 (Lee 2009). Because our randomization was conducted with a small number of clusters, we also present finite sample randomization inference p-values in column 6 . These yield strong evidence that the controlintervention test score differences we estimate are not likely to be the result of differential attrition or chance.

We include three additional transformations of the primary outcome in Table 4, Panel B. First, we show the effect of the intervention on the proportion of children with a score of exactly zero on the composite exam. Roughly five percent of control children score exactly zero, while

\footnotetext{
${ }^{18}$ The adjusted difference is the intervention-control difference for a given variable after controlling for stratification variables as pre-specified for our main analysis; equivalently, this is the regression coefficient on the intervention variable using our main regression specification.

${ }^{19}$ Were we to use the control SD as a scale factor, the 58.1 percent difference in scores would correspond to a 5.31 SD difference in test scores between the two groups.
} 
no intervention children register this score. This suggests that while learning levels are very low, the EGRA and EGMA tests we used were successful in avoiding floor effects.

Second, we estimate the impact of the intervention on literacy and numeracy, rather than just the reading and math test scores. It is generally accepted that children are considered proficient readers when they read "with good fluency" (at least 45 words per minute) and can correctly answer $80 \%$ or more of the reading comprehension questions associated with the text read (Dubeck and Gove 2015). Using this classification to generate a binary variable for literacy, we find that the intervention raises literacy rates by 62.9 percentage points, from a baseline of less than a tenth of a percent of control children reaching literacy. Unfortunately, there is no similar consensus on the definition of numeracy. Using benchmarks from USAID work in Ghana $^{20}$, we can create a binary numeracy variable equal to one if the child completes at least $70 \%$ of the missing number sequence questions correctly (subtask 3 ) and at least $80 \%$ of the word problem questions correctly (subtask 6). Under this definition, the intervention raises numeracy by 20.5 percentage points, compared to precisely zero control children reaching this level, as reported in Table 4. This is a stringent definition of numeracy; for reference, in 2013 less than $4 \%$ of Ghanaian schoolchildren achieved this level of performance on these two subtasks. We also create a variable capturing more basic numeracy skills: the child's ability to compare the magnitude of pairs of two- or three- digit numbers (subtask 2) and compute simple

\footnotetext{
${ }^{20}$ Source: https://pdf.usaid.gov/pdf_docs/PA00KS7N.pdf, accessed January $20^{\text {th }}, 2021$.
} 
sums (subtask 4a). Using this measure, we estimate a treatment effect of the intervention on

basic child numeracy of 71.5 percentage points (not reported in the table).

Table 4. EGRA and EGMA total scores

\begin{tabular}{|c|c|c|c|c|c|c|}
\hline Variable & $\begin{array}{c}\text { (1) } \\
\text { Intervention } \\
\text { (SD) } \\
\end{array}$ & $\begin{array}{c}(2) \\
\text { Control } \\
\text { (SD) } \\
\end{array}$ & $\begin{array}{c}(3) \\
\text { Adjusted } \\
\text { difference } \\
\text { (SE) } \\
\end{array}$ & $\begin{array}{c}\text { (4) } \\
\text { Conven- } \\
\text { tional } \\
\text { p-value }\end{array}$ & $\begin{array}{c}\text { (5) } \\
\text { Lee } \\
\text { Bounds } \\
\text { (SE) } \\
\end{array}$ & $\begin{array}{c}\text { (6) } \\
\text { RI finite } \\
\text { sample } \\
\text { p-value }\end{array}$ \\
\hline \multicolumn{7}{|c|}{ Panel A: Pre-specified outcomes } \\
\hline $\begin{array}{l}\text { Composite } \\
\text { test score }\end{array}$ & $\begin{array}{l}70.48 \\
(15.35)\end{array}$ & $\begin{array}{c}11.21 \\
(10.93)\end{array}$ & $\begin{array}{l}58.14 \\
(1.28)\end{array}$ & $\mathrm{p}<0.001$ & $\begin{array}{l}\text { L: } 55.04(1.27) \\
\text { U: } 63.20(1.25)\end{array}$ & $\mathrm{p}<0.001$ \\
\hline $\begin{array}{l}\text { Reading } \\
\text { score }\end{array}$ & $\begin{array}{l}72.48 \\
(17.07)\end{array}$ & $\begin{array}{c}6.84 \\
(8.85)\end{array}$ & $\begin{array}{l}64.44 \\
(0.98)\end{array}$ & $\mathrm{p}<0.001$ & $\begin{array}{l}\text { L: } 60.57(1.09) \\
\text { U: } 69.73(1.17)\end{array}$ & $\mathrm{p}<0.001$ \\
\hline $\begin{array}{l}\text { Math } \\
\text { score }\end{array}$ & $\begin{array}{l}68.48 \\
(16.55)\end{array}$ & $\begin{array}{c}15.58 \\
(14.82)\end{array}$ & $\begin{array}{l}51.85 \\
(1.83)\end{array}$ & $\mathrm{p}<0.001$ & $\begin{array}{l}\text { L: } 48.87(1.71) \\
\text { U: } 57.67(1.69)\end{array}$ & $\mathrm{p}<0.001$ \\
\hline \multicolumn{7}{|c|}{ Panel B: Summary measures } \\
\hline $\begin{array}{l}\text { Composite test } \\
\text { score is zero }\end{array}$ & $\begin{array}{l}0 \% \\
(0)\end{array}$ & $\begin{array}{l}5.18 \% \\
(22.17)\end{array}$ & $\begin{array}{c}-4.02 \% \\
(1.16)\end{array}$ & $\mathrm{p}=0.001$ & $--^{*}{ }^{*}{ }^{*}$ & $\mathrm{p}=0.032$ \\
\hline $\begin{array}{l}\text { Child is } \\
\text { literate }\end{array}$ & $\begin{array}{l}63.94 \% \\
(48.06)\end{array}$ & $\begin{array}{l}0.09 \% \\
(3.04)\end{array}$ & $\begin{array}{l}62.91 \% \\
(2.01)\end{array}$ & $\mathrm{p}<0.001$ & $\begin{array}{l}\text { L: } 54.15(2.91) \\
\text { U: } 72.04(3.70)\end{array}$ & $\mathrm{p}<0.001$ \\
\hline $\begin{array}{l}\text { Child is } \\
\text { numerate** }\end{array}$ & $\begin{array}{l}21.31 \% \\
(40.99)\end{array}$ & $\begin{array}{l}0 \% \\
(0)\end{array}$ & $\begin{array}{l}20.49 \% \\
(2.73)\end{array}$ & $\mathrm{p}<0.001$ & $\begin{array}{c}\text { L: } 4.96(4.49) \\
\text { U: } 22.14(2.78)\end{array}$ & $\mathrm{p}<0.001$ \\
\hline Observations & 563 & 1,081 & -- & -- & -- & -- \\
\hline
\end{tabular}

Table 4 notes: columns 1 and 2 show the group-specific mean test scores (group-specific SD in parentheses below). Column 3 shows the adjusted difference between the two groups (i.e., the coefficient on the intervention variable in a linear regression, estimated with the inclusion of a control for the stratum variable) with standard errors, clustered at the village level, below in parentheses. Column 4 shows the p-value of a test that this difference is equal to zero. Column 5 shows Lee bounds on the estimate in column 3. Column 6 shows exact randomization inference p-values of the adjusted difference. ${ }^{*}$ : Estimation of Lee bounds are degenerate for this variable due to there being zero observations with composite score equal to zero in the intervention group and a small number of observations with composite score equal to zero in the control group. Because of this, we do not report them. ${ }^{* *}$ : As discussed in the text, the measure of numeracy used here is less well-established and relatively stringent. Using a measure of more basic numeracy (consistently recognizing which of two distinct two- or three-digit numbers is larger and successfully performing at least half of simple addition tasks), we estimate a treatment effect of the intervention on basic numeracy of 71.5 percentage points. 


\section{Figure 1. Distribution of test scores, by treatment group}

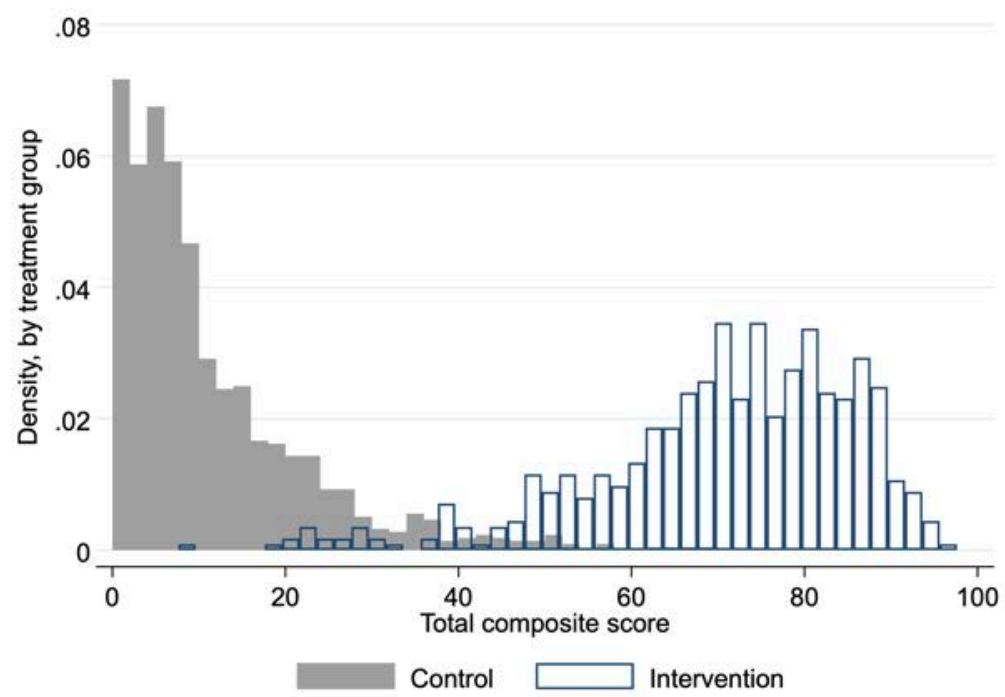

Figure 1 notes: this figure shows the distribution of the composite test score for the control and intervention groups, separately, for all children who took the endline test.

\subsection{Reading}

In this section, we describe the results of the EGRA test in greater detail. These are shown in Table 5. In this table, we show three scores for each subtask: i) the average percent correct, ii), for timed subtasks, the fluency scores, and iii) the percent of children with a zero score.

Intervention children substantially outperformed control children in reading: in all subtasks, the control-intervention difference in the percent of correct answers is at least 42 percentage points (out of 100). Children in the intervention group demonstrated reading skill mastery across subtasks of all difficulty levels. They were able to correctly read more than two thirds of the letters presented to them (under a one minute time limit). For familiar word reading, the mean intervention child read 79 percent of the 50 words presented correctly in one minute. For connected text reading, the intervention children achieve a mean reading fluency of 75 words per minute, which is higher than the defined reading proficiency benchmark for Grade 3 in most of the EGRA countries (RTI International 2017). It is also much higher than oral reading fluency measures from other African countries who have used EGRA: average grade 3 oral reading 
fluency in English-speaking African countries is 9.2, and in Francophone African countries it is 32.4 (USAID 2019) and comparable to EGRA results from wealthier Latin American countries, such as Guatemala, Jamaica, and Peru. Average oral reading fluency in Latin America is 73 words per minute in English, and 79 in Spanish. For the untimed tasks, the pattern was roughly the same. In the subtask measuring children's comprehension of a connected text, the mean score for intervention children was $72 \%$ of questions answered correctly. For the control group, it was one percent.

Table 5. EGRA subtasks

\begin{tabular}{|c|c|c|c|c|c|c|c|c|c|}
\hline \multirow[b]{2}{*}{ Subtask } & \multicolumn{3}{|c|}{ Percent correct } & \multicolumn{3}{|c|}{ Fluency scores } & \multicolumn{3}{|c|}{ Percent with zero score } \\
\hline & Interv. & Control & p-value & Interv. & Control & p-value & Interv. & Control & p-value \\
\hline $\begin{array}{l}\text { Letter } \\
\text { recognition (1) }\end{array}$ & $68.3 \%$ & $11.5 \%$ & $\mathrm{p}<0.001$ & 68.7 & 11.4 & $\mathrm{p}<0.001$ & $0.0 \%$ & $35.2 \%$ & $\mathrm{p}<0.001$ \\
\hline $\begin{array}{l}\text { Initial sound } \\
\text { recognition (2) }\end{array}$ & $63.1 \%$ & $20.9 \%$ & $\mathrm{p}<0.001$ & --- & --- & --- & $3.7 \%$ & $43.0 \%$ & $\mathrm{p}<0.001$ \\
\hline $\begin{array}{l}\text { Invented-word } \\
\text { reading ( } 3 \text { ) }\end{array}$ & $58.0 \%$ & $2.3 \%$ & $\mathrm{p}<0.001$ & 29.3 & 1.2 & $\mathrm{p}<0.001$ & $1.6 \%$ & $90.6 \%$ & $\mathrm{p}<0.001$ \\
\hline $\begin{array}{l}\text { Familiar word } \\
\text { reading (4) }\end{array}$ & $79.1 \%$ & $2.7 \%$ & $\mathrm{p}<0.001$ & 45.5 & 1.3 & $\mathrm{p}<0.001$ & $1.2 \%$ & $88.8 \%$ & $\mathrm{p}<0.001$ \\
\hline $\begin{array}{l}\text { Oral reading } \\
\text { fluency* }(5 \mathrm{a})\end{array}$ & $86.9 \%$ & $4.3 \%$ & $\mathrm{p}<0.001$ & 75.1 & 2.9 & $\mathrm{p}<0.001$ & $0.2 \%$ & $59.1 \%$ & $\mathrm{p}<0.001$ \\
\hline $\begin{array}{l}\text { Reading comp- } \\
\text { rehension }(5 b)\end{array}$ & $72.3 \%$ & $1.1 \%$ & $\mathrm{p}<0.001$ & --- & --- & --- & $2.8 \%$ & $95.9 \%$ & $\mathrm{p}<0.001$ \\
\hline $\begin{array}{l}\text { Listening comp- } \\
\text { rehension (6) }\end{array}$ & $79.7 \%$ & $5.1 \%$ & $\mathrm{p}<0.001$ & --- & --- & --- & $6.2 \%$ & $89.2 \%$ & $\mathrm{p}<0.001$ \\
\hline Observations & 563 & 1,081 & --- & 563 & 1,081 & --- & 563 & 1,081 & --- \\
\hline
\end{tabular}

Table 5 notes: this table shows the mean percent of correct answers, fluency scores, and zero scores on the individual components of the reading test by treatment group. The number in parentheses next to each subtask label corresponds to the subtask number given in Table A.2. *: The lower proportion of control group zero scores on subtask $5 \mathrm{a}$ is a result of the fact that the first question in this subtask happened to be substantially less difficult than the questions asking children to read familiar or made-up words in subtasks 3 and 4 . For each type of score (percent correct, fluency, zero score) we also include the p-value from a test that the difference between intervention and control values of a given subtask is zero. 
Another meaningful comparison in EGRA- and EGMA-style tests is the proportion of children with zero correct answers (i.e., "zero score") in each subtask. We show this in the three right-most columns of Table 5. These data highlight the exceptionally low learning levels among the control group. In four of the five most difficult reading subtasks, 88 percent or more of the control group earned zero scores. For example, more than 88 percent of the control children tested at endline were unable to read even one of the 50 familiar words presented, compared to only 1.2 percent of children in the intervention group (subtask 4). Similar patterns appear across all subtasks involving reading or oral comprehension, corroborating the very low levels of literacy found in Boone et al. (2014).

\subsection{Math}

Next, we discuss children's performance, by intervention arm, on math subtasks. We present these results in Table 6, mirroring the format of Table 5. Children in intervention villages also dramatically outperformed children in control villages in terms of math ability, as seen in scores for all subtasks. Intervention children could solve around 15 simple addition problems and around 10 simple subtraction problems per minute, compared with around three addition problems and one subtraction problem for control children, respectively. This suggests intervention children were at least five times more "fluent" in these core arithmetic skills, fundamental and important predictors for subsequent mathematical development (Jordan et al. 2009). For two-digit problems, some with borrowing/carrying, intervention children answered $55 \%$ of addition problems and $33 \%$ of subtraction problems correctly, compared with $3.5 \%$ and $1 \%$, respectively, for control children. For the subtask that evaluates children's ability to discern and complete number patterns - EGMA subtask 3, identifying the missing number in a sequence such as $[2,4,6, \ldots]$ - more than half of the intervention group correctly answered $60 \%$ or more 
of the questions. This would be classified as reaching a desired level of performance in this skill for third grade students in several other countries which use the EGMA test to assess child learning (RTI International 2009). Only around $0.2 \%$ of the control group score this well on subtask 3. As with reading, far fewer intervention children had zero scores on math subtasks than did control children, with larger control/intervention gaps for more difficult subtasks.

Table 6. EGMA subtasks

\begin{tabular}{|c|c|c|c|c|c|c|c|c|c|}
\hline \multirow[b]{2}{*}{ Subtask } & \multicolumn{3}{|c|}{ Percent correct } & \multicolumn{3}{|c|}{ Fluency scores } & \multicolumn{3}{|c|}{ Percent with zero score } \\
\hline & Interv. & Control & p-value & Interv. & Control & p-value & Interv. & Control & p-value \\
\hline $\begin{array}{l}\text { Number } \\
\text { identification (1) }\end{array}$ & $96.7 \%$ & $30.6 \%$ & $\mathrm{p}<0.001$ & 47.7 & 7.3 & $\mathrm{p}<0.001$ & $0.0 \%$ & $15.5 \%$ & $\mathrm{p}<0.001$ \\
\hline $\begin{array}{l}\text { Quantitative } \\
\text { comparisons (2) }\end{array}$ & $89.7 \%$ & $19.9 \%$ & $\mathrm{p}<0.001$ & --- & --- & --- & $0.2 \%$ & $41.4 \%$ & $\mathrm{p}<0.001$ \\
\hline $\begin{array}{l}\text { Missing } \\
\text { number (3) }\end{array}$ & $64.7 \%$ & $11.0 \%$ & $\mathrm{p}<0.001$ & --- & --- & --- & $0.5 \%$ & $41.6 \%$ & $\mathrm{p}<0.001$ \\
\hline $\begin{array}{l}\text { Addition } \\
\text { level } 1 \text { (4a) }\end{array}$ & $67.0 \%$ & $10.7 \%$ & $\mathrm{p}<0.001$ & 14.6 & 2.7 & $\mathrm{p}<0.001$ & $1.6 \%$ & $52.8 \%$ & $\mathrm{p}<0.001$ \\
\hline $\begin{array}{l}\text { Addition } \\
\text { level } 2^{*}(4 \mathrm{~b})\end{array}$ & $54.8 \%$ & $3.5 \%$ & $\mathrm{p}<0.001$ & --- & --- & --- & $9.2 \%$ & $88.5 \%$ & $\mathrm{p}<0.001$ \\
\hline $\begin{array}{l}\text { Subtraction } \\
\text { level } 1 \text { (5a) }\end{array}$ & $45.6 \%$ & $4.5 \%$ & $\mathrm{p}<0.001$ & 9.6 & 1.3 & $\mathrm{p}<0.001$ & $4.3 \%$ & $72.5 \%$ & $\mathrm{p}<0.001$ \\
\hline $\begin{array}{l}\text { Subtraction } \\
\text { level } 2^{*}(5 b)\end{array}$ & $33.0 \%$ & $1.0 \%$ & $\mathrm{p}<0.001$ & --- & --- & --- & $28.2 \%$ & $95.8 \%$ & $\mathrm{p}<0.001$ \\
\hline $\begin{array}{l}\text { Word } \\
\text { problems (6) }\end{array}$ & $52.0 \%$ & $18.8 \%$ & $\mathrm{p}<0.001$ & --- & --- & --- & $5.7 \%$ & $37.7 \%$ & $\mathrm{p}<0.001$ \\
\hline Observations & 563 & 1,081 & --- & 563 & 1,081 & --- & 563 & 1,081 & --- \\
\hline
\end{tabular}

Table 6 notes: this table shows the mean percent of correct answers, fluency scores, and zero scores on the individual components of the math test by treatment group. The number in parentheses next to the subtask label corresponds to the subtask number given in Table A.2. There are 6-40 missing values in some timed subtasks; adjusting for these missing values changes the fluency score estimates by $0.01-0.35$. Given the large interventioncontrol differences in fluency scores, we do not report these sensitivity analyses here. *: Level 2 subtasks were only administered to children with non-zero scores in addition level 1 and subtraction level 1, respectively. For each type of score (percent correct, fluency, zero score) we also include the p-value from a test that the difference between intervention and control values of a given subtask is zero. 
Table 7. Composite test scores by subgroup, with interaction tests

\begin{tabular}{|c|c|c|c|c|}
\hline Group & $\begin{array}{c}\text { (1) } \\
\text { Intervention } \\
\text { (SD) }\end{array}$ & $\begin{array}{c}\text { (2) } \\
\text { Control } \\
\text { (SD) }\end{array}$ & $\begin{array}{c}(3) \\
\text { Adjusted } \\
\text { difference } \\
\text { (SE) } \\
\end{array}$ & $\begin{array}{c}\text { (4) } \\
\text { p-value }\end{array}$ \\
\hline \multicolumn{5}{|c|}{ Child gender } \\
\hline $\begin{array}{l}\text { Male } \\
(\mathrm{N}: \mathrm{I}=297, \mathrm{C}=586) \\
\text { Female } \\
(\mathrm{N}: \mathrm{I}=266, \mathrm{C}=495)\end{array}$ & $\begin{array}{c}72.57 \\
(14.07) \\
68.14 \\
(16.37)\end{array}$ & $\begin{array}{c}12.58 \\
(11.49) \\
9.59 \\
(9.99)\end{array}$ & $\begin{array}{l}58.89 \\
(1.40) \\
57.41 \\
(1.38)\end{array}$ & 0.188 \\
\hline \multicolumn{5}{|c|}{ Household wealth* } \\
\hline $\begin{array}{l}\text { Low wealth index } \\
(\mathrm{N}: \mathrm{I}=227, \mathrm{C}=489) \\
\text { High wealth index } \\
(\mathrm{N}: \mathrm{I}=320, \mathrm{C}=475)\end{array}$ & $\begin{array}{c}70.47 \\
(15.60) \\
71.03 \\
(14.37)\end{array}$ & $\begin{array}{c}10.73 \\
(10.05) \\
12.08 \\
(11.73)\end{array}$ & $\begin{array}{l}58.59 \\
(1.78) \\
58.15 \\
(1.52)\end{array}$ & 0.835 \\
\hline \multicolumn{5}{|c|}{ Mother's education } \\
\hline $\begin{array}{l}\text { No education } \\
(\mathrm{N}: \mathrm{I}=366, \mathrm{C}=765) \\
\text { At least grade } 1 \text { education } \\
(\mathrm{N}: \mathrm{I}=197, \mathrm{C}=316)\end{array}$ & $\begin{array}{c}69.41 \\
(15.80) \\
72.46 \\
(14.30)\end{array}$ & $\begin{array}{c}10.23 \\
(10.19) \\
13.59 \\
(12.23)\end{array}$ & $\begin{array}{l}58.21 \\
(1.45) \\
57.98 \\
(1.63)\end{array}$ & 0.900 \\
\hline \multicolumn{5}{|c|}{ Father's education } \\
\hline $\begin{array}{l}\text { No education } \\
(\mathrm{N}: \mathrm{I}=157, \mathrm{C}=335) \\
\text { At least grade } 1 \text { education } \\
(\mathrm{N}: \mathrm{I}=406, \mathrm{C}=746)\end{array}$ & $\begin{array}{c}70.83 \\
(15.45) \\
70.35 \\
(15.32)\end{array}$ & $\begin{array}{c}9.72 \\
(10.29) \\
11.88 \\
(11.15)\end{array}$ & $\begin{array}{l}60.24 \\
(1.41) \\
57.24 \\
(1.41)\end{array}$ & 0.025 \\
\hline
\end{tabular}

Table 7 notes: this table follows the format of columns 1-4 in Table 4. It shows group-specific means and standard deviation in parentheses below) in columns 1 and 2, and control/intervention differences in children's scores on the composite test by subgroup in column 3 (with standard errors, clustered at the village level, in parentheses below). P-values are for tests of the null of an equal effect of the intervention across subgroups, estimated by calculating the p-value on an interaction term between the treatment variable and the subgroup indicator variable. *: The wealth index is high if the caregiver reports 1) that they could find money to pay a sudden medical bill of 42,000 CFA (roughly US \$72), and 2) that in the last year their family went no longer than one month without income; it is low otherwise.

\subsection{Heterogeneity in effect size for the primary outcome}

In this section, we present a series of pre-specified and exploratory tests for heterogeneity in the effect of the intervention. First, we present our pre-specified tests across a series of demographic characteristics, shown in Table 7. We investigate differential effects of the treatment by child gender, a proxy for the wealth of the family, and the level of education of the child's mother and, 
separately, father. We see large control-intervention test score differences across all subgroups, but the only statistically significant dimension of heterogeneity is for father's education, and this result is not robust to standard adjustments for multiple hypothesis testing, such as a Bonferroni adjustment (List, Shaikh, and Xu 2019). ${ }^{21}$

We next report results of exploratory heterogeneity analysis by characteristics of the school in the village. All but one village had some sort of school in it at baseline. We conduct our analyses based on the number of teachers in the village, the type of school in the village, the highest grade taught in the school, and the quality of the school infrastructure, proxied by the material of its roof. We show these results in Table A.4. We find no evidence of meaningful heterogeneity in the effect of the intervention along any of these dimensions, consistent with the consensus from prior work showing that, in rural areas like those we study, existing variation in school type, school resources, and even teacher credentials generate very little variation in student learning levels (Daun 1997; Boone et al. 2014; da Silva and Oliveira 2017).

\subsection{Other effects}

In this section we discuss the impact of the intervention on children's enrollment in school and their grade progression. In Table 8, we report a pre-specified analysis of enrollment in school and an exploratory analysis of grade progression. We first estimate the impact of the intervention on the proportion of children in each randomization group enrolled in school at the midline and endline of the study. At midline in 2014, approximately $97 \%$ of intervention children were enrolled in school, while only $64 \%$ of control children were. This gap narrows at endline in

\footnotetext{
${ }^{21} \mathrm{We}$ also pre-specified heterogeneity tests by the village's distance to the main road, whether the child most commonly speaks Crioulo, as opposed to other languages, and whether there was an economic shock to the main breadwinner of the child's family during the course of the trial. We found no evidence of heterogeneity on these dimensions and do not present these analyses here for the sake of brevity.
} 
2016, driven largely by an increase in enrollment among the control group: $97 \%$ of intervention children were enrolled in school at the end of the trial, while $85 \%$ of control children were.

Table 8. Enrollment and progression in school

\begin{tabular}{|c|c|c|c|c|c|}
\hline \multicolumn{6}{|c|}{ Panel A: Child is enrolled in school } \\
\hline Date of measurement & $\begin{array}{c}\text { (1) } \\
\text { Intervention } \\
\text { (N) }\end{array}$ & $\begin{array}{c}(2) \\
\text { Control } \\
(\mathbf{N})\end{array}$ & $\begin{array}{c}\text { (3) } \\
\text { Adjusted } \\
\text { difference } \\
(\mathrm{SE}) \\
\end{array}$ & $\begin{array}{c}(4) \\
\text { Odds Ratio } \\
(95 \% \text { CI) }\end{array}$ & $\begin{array}{c}(5) \\
\text { p-value }\end{array}$ \\
\hline $\begin{array}{l}\text { At midline }(2015) \\
(\mathrm{N}: \mathrm{I}=629, \mathrm{C}=1,379)\end{array}$ & $\begin{array}{l}96.82 \% \\
(609)\end{array}$ & $\begin{array}{l}63.96 \% \\
(882)\end{array}$ & $\begin{array}{l}31.68 \% \\
(3.84)\end{array}$ & $\begin{array}{c}15.27 \\
(9.16,25.46)\end{array}$ & $\mathrm{p}<0.001$ \\
\hline $\begin{array}{l}\text { At endline }(2017) \\
(\mathrm{N}: \mathrm{I}=611, \mathrm{C}=1,354)\end{array}$ & $\begin{array}{c}97.05 \% \\
(593)\end{array}$ & $\begin{array}{l}84.72 \% \\
(1,148)\end{array}$ & $\begin{array}{c}10.90 \% \\
(2.54)\end{array}$ & $\begin{array}{c}5.00 \\
(2.48,10.07)\end{array}$ & $\mathrm{p}<0.001$ \\
\hline
\end{tabular}

Panel B: Child's grade in school at endline

\begin{tabular}{lcccc}
\hline Grade in school & $\begin{array}{c}\text { (1) } \\
\text { Number of } \\
\text { intervention } \\
\text { children }\end{array}$ & $\begin{array}{c}\text { (2) } \\
\text { Number of } \\
\text { control } \\
\text { children }\end{array}$ & $\begin{array}{c}\text { Effect of intervention on probability child is } \\
\text { in grade 2 or higher at endline } \\
\text { (3) }\end{array}$ \\
\hline Not enrolled & 18 & 71 & $\begin{array}{c}\text { Estimated effect (SE) } \\
\text { p-value }\end{array}$ \\
Pre-school & 2 & 29 & $(3.79)$ & \\
Grade 1 & 11 & 743 & & \\
Grade 2 & 20 & 254 & & \\
Grade 3 & 527 & 43 & & \\
Grade 4 or 5 & 15 & 8 & \\
Number of observations & 593 & 1,148 & \\
\hline \hline
\end{tabular}

Table 8 notes: in Panel A, we show the proportion of students enrolled in school, in each group, at the time of midline and endline surveys. Column 3 shows the adjusted difference as in earlier tables, column 4 shows the odds ratio, and column 5 shows the p-value for a test of the null hypothesis of equal enrollment across treatment groups, as was pre-specified. In Panel B, we show the grade in which children were enrolled in school at the time of the endline survey. In the right of the table, we show our exploratory (not pre-specified) estimate of the effect of the intervention on the probability a child is enrolled in at least grade 2 at endline using our main specification and the $\mathrm{p}$-value for a test of the null hypothesis that there was no effect. 
These differences are both statistically significant. We see the intervention also has a large impact on grade progression. At endline, intervention children are 65.5 percentage points more likely to be enrolled in at least the second grade, relative to control children.

We also collected parents' report of whether or not the child missed any school in the past two weeks at the midline and endline surveys. In Figure A.3, we show these results, which suggest that intervention children are much less likely than control children to miss school in both AY 2014-15 and AY 2016-17. Because we are missing attendance data for many of these children, particularly for controls, we have put these particular results in the appendix and urge caution in their interpretation.

At endline, we collected information from the child's nearest older sibling and nearest younger sibling about their enrollment in school up to that point. We also administered simple ASER-style reading and math tests (Pratham 2010). We were only able to locate siblings in between 25 and 40 percent of cases. Of the siblings we did find, we found little difference in enrollment in school (see Table A.5). Nonetheless, among these children we found significantly higher literacy and numeracy among the intervention group for both older and younger siblings. We show these differences in Figure A.4. This suggests potential spillovers of learning to siblings, with two important caveats. First, the magnitudes of the differences are very small compared to the differences we find for study children. Second, because roughly 70 percent of siblings were not found, we are hesitant to draw strong conclusions from these analyses.

\subsection{Benefit-cost analysis}

We estimate that this intervention would cost approximately US $\$ 1,700$ per child to run for four 
years; equivalently, the per-child, per-year cost is roughly $\$ 425 .{ }^{22}$ While this is a very highlyresourced intervention relative to others in this literature, such as those described in Kremer, Brannen, and Glennerster (2013), it achieves learning gains of unprecedented magnitude in an exceedingly challenging environment.

We provide a rough estimate of a lower bound for the benefit-cost ratio of this intervention (Levin et al. 2017). To generate our assumption about the per-person benefit, we need an approximation of the income premium that achieving literacy and numeracy might yield later in life. To generate this, we use the following assumptions. One, using estimates from Table 4, we assume that the intervention generates a 62.9 percentage point increase in the likelihood a child will be literate. Two, we assume that, as a result, the child's future employment is characterized by the following probability set: they continue subsistence farming ( $30 \%$ chance), they work in their village for a local NGO (30\% chance) they become a community teacher $(30 \%$ chance), or they progress in school until the $12^{\text {th }}$ grade, at which point they gain employment in a national NGO (10\% chance) ${ }^{23}$ We estimate the lifetime gain in income, over a baseline of subsistence farming with certainty, given current salaries for these positions ${ }^{24}$, and assuming a 5\% annual GDP growth rate (The World Bank 2019) and a 5\% annual discount rate (Duflo 2001). Finally, we assume that affected individuals work from age 17 to age 55, during which time they earn the income benefit assumed above.

\footnotetext{
${ }^{22}$ To calculate the cost of our project, we use the projected costs for the ongoing (at time of writing) expansion of the project. We chose this instead of the actual costs incurred during the implementation of this study because of the costs incurred during the previously described challenges with early implementation. Without dramatic assumptions, it is not clear how to extract the "true" costs of the final project from those data (e.g., the "right-sizing" of administration, procurement, and other costs for this smaller scale).

${ }^{23} \mathrm{We}$ generated these probabilities based on our understanding of the local labor markets and discussion with project staff.

${ }^{24}$ NGO community worker salary: 15,000 CFA per month for 12 months per year. Community teacher salary: 25,000 per month for 9 months per year. National NGO salary: 100,000 CFA per month for 12 months per year.
} 
Using these assumptions, our intervention has a benefit-cost ratio of at least 3.12. We expect this to be a lower bound on the true ratio, given the various, harder-to-estimate returns to literacy and numeracy that accrue in health, longevity, and welfare more broadly (Dickson and Harmon 2011). This ratio suggests the intervention is highly cost-efficient, and compares favorably with many other studies in similar contexts (Evans and Popova 2016).

An increasingly common approach to this type of analysis is to calculate the "marginal value of public funds" or MVPF (Hendren and Sprung-Keyser 2020). This calculates the aftertax benefit to participants, accounting for changes in tax revenue because of the program. These changes can be negative (e.g., distorting behavior away from productive activity in order to qualify for the program) or positive (e.g., generating externalities). In Guinea Bissau, the effective tax rate is zero for most people, as most government revenue comes from two sources: cashew nut exports and foreign aid. We assume, therefore, that there are no negative externalitytype changes in revenue that would accrue from implementing this policy. The likely positive externalities of the policy - greater economic, health, and political benefits from a higher literacy rate - make our benefit-cost calculation a lower bound on the true benefit-cost ratio.

\section{Features, uniqueness, and scalability of the intervention}

In this section, we discuss potential explanations for the large magnitude of the results we find, describing what features of the intervention are unique and its potential for scalability.

We think there are two core reasons for the large impacts we observe. First, the intervention's focus was on child learning, as opposed to test score improvement or child or teacher attendance. All implementers, from teachers to monitors to senior staff, understood that learning was the main objective. This focus informed the design of all teaching and learning materials, from textbooks to teacher handbooks and lesson plans. These materials also 
incorporated scripted lessons, which have been shown to work in numerous settings (Piper et al. 2018; Romero, Sandefur, and Sandholtz 2020; Eble et al. 2021) and are alleged to be particularly helpful for teachers with less training and suboptimal supervision, potentially raising the level of the "floor" of teaching quality in challenging contexts. The absence of heterogeneity in the treatment effect shows the intervention worked similarly for all children. This is a common feature of scripted lessons (Muralidharan, Singh, and Ganimian 2019) and suggests the important contribution of scripting in generating our effects.

Second, we conducted regular, in-depth, and responsive monitoring of both student learning and, separately, teaching. This is in stark contrast to the control condition, where there is little monitoring of teaching or student learning. Monitoring focused on improving teaching skill, not just teacher attendance. The intervention invested heavily in teachers, including three months of pre-service training in how to use the intervention's pedagogical model and materials and ongoing training in how to teach new content using new lesson plans. The intervention employed two tiers of monitoring staff who observed teachers, provided feedback, and used these lessons to guide subsequent training. This pairing of monitoring and training with the goal of improving teacher practice has previously yielded large improvements in learning across diverse settings (Piper et al. 2018; Eble et al. 2021), and likely made an important contribution to the intervention's success. In addition, the intervention team measured child learning regularly through in-class tests and periodic external testing, ${ }^{25}$ monitoring results and giving teachers of lagging students extra attention or assistance. The team also worked with parents to ensure child attendance in classes and provided additional after-school support to struggling students. Other

\footnotetext{
${ }^{25}$ These tests were designed in-house and deliberately diverged from EGRA- and EGMA-style tests to ensure that we were not "teaching to the test."
} 
clear contributors include increased instructional time and resources provided, though extra time and money are no guarantee of a large effect (Woessmann 2016; De Ree et al. 2018). ${ }^{26}$

We believe that efficient implementation of these core components could lead to quality education in many other contexts, even in the absence of a large influx of resources. As described in Bold et al. (2018) and Banerjee et al. (2017), however, an important challenge is stakeholder buy-in. Implementing such a system would constitute a large change in focus and responsibilities from teaching and support staff, which may meet resistance. Nonetheless, we think that our results provide important guidance on how to proceed in poor, remote areas such as the one we study. Furthermore, our ongoing work shows that this model is scalable. ${ }^{27}$ Aside from buy-in, the main barrier to scalability, as we see it, is resources. Implemented outside of the government, this is a highly expensive intervention. Implemented within the government, we anticipate both political and logistical challenges to widespread adoption (c.f., Bold et al. 2018).

There are two other important potential explanations for our results: teaching to the test and test floor effects. We use EGRA and EGMA tests precisely because they focus on the skills necessary to read, make sense of written content, to do arithmetic, and to make sense of simple arithmetic expressions. These skills are aligned with the goals for almost all education systems at this level of learning and, in many other contexts, EGRA and EGMA tests are used by government itself to measure learning (Sprenger-Charolles 2008; USAID 2019). The second potential contributor is floor effects, i.e., that the tests were not sensitive enough to pick up very

\footnotetext{
${ }^{26}$ Intervention students had an additional hour per day in school, and our schools did not suffer from the teacher strikes that occurred in government schools over the period of our study. The absence of a difference in effect size between villages with and without a government school suggests that more instructional time does not necessarily translate into learning in this context. The long literature on credit constraints in education shows both theoretically and empirically that, in such areas, private provision of education is also particularly likely to under-supply quality (c.f., Becker 1994; Lochner and Monge-Naranjo 2012; Heckman and Mosso 2014).

${ }^{27}$ In response to the preliminary results of this study, we are on track to scale up the intervention in Guinea Bissau to an additional 2,000 children. In Telangana, India, and The Gambia, we have scaled up a para-teacher intervention with similar foci to 15,000 and 4,000 children, respectively.
} 
basic skills. EGRA and EGMA tests are designed to be particularly sensitive at measuring low levels of learning (Platas et al. 2014; Dubeck and Gove 2015). Comparing subtasks where the control group has a substantial amount of nonzero scores provides little evidence of floor effects. ${ }^{28}$ The small proportion of absolute zero composite scores shown in Table 4 further suggests that our tests were sufficiently sensitive for measuring learning in this population.

Our study design did not attempt to identify individual mechanisms behind our intervention. Instead, we targeted areas with great need and evaluated a comprehensive intervention to dramatically increase learning levels in them. This "bundled" approach is in the spirit of the multifaceted poverty alleviation program studied by Banerjee et al. (2015). This does not allow us to isolate mechanisms driving the results we observe, though we speculate that there are complementarities between the individual components, as in Mbiti et al. (2019).

At the outset, we were unsure whether such an intervention would work. If demand factors explained most of the lack of schooling - i.e., parents and their children do not believe education merits the opportunity cost - then the poor outcomes of children might not be impacted by changes to the provision of schooling. Furthermore, as we experienced, implementation challenges could have derailed our efforts entirely and it is important to document this. We also show the costs of implementing such a program in an exceedingly deprived and difficult environment. Due to the fragility of the state in Guinea Bissau, public institutions such as schools, customs, and the courts often function poorly or not at all (Sangreman, Delgado, and Martins 2018). Working in hard-to-reach, extremely poor regions

\footnotetext{
${ }^{28}$ We generate this "alternate composite score" by calculating the arithmetic mean of average performance on EGMA subtasks 1-4a and on EGRA subtasks 1-2. Using this yields a treatment effect estimate of 54.08 percentage points, as compared to 58.14 percentage points using the original composite score.
} 
within Guinea Bissau made provision even more expensive, and logistics more difficult, than in the country's urban or peri-urban areas.

The other main contributor to the large difference between children in control and intervention villages is, sadly, the failure of the state and other actors to deliver education in these areas. Education levels in Guinea Bissau have remained consistently low over the last fifty years, and there is little evidence that, in the absence of external intervention such as ours, this is likely to change (Daun 1997; Boone et al. 2014; da Silva and Oliveira 2017). During the course of our study, government provision of education in the control villages, as in the rest of the country, was of low quality and sometimes erratic. The counterfactual case, therefore, is one in which many children reach adulthood without achieving meaningful levels of literacy and numeracy. We expect that it is easier to raise learning from such a low baseline than it would be in contexts with higher learning levels.

\section{Conclusion}

In the least fortunate parts of the developing world, many children receive schooling which is unable to teach them even basic literacy and numeracy. We ran an RCT in rural Guinea Bissau to evaluate an intervention that provided schooling in lieu of the state and other status quo providers for four years. We find the intervention yielded dramatic increases in learning among recipient children, leading them to be functionally numerate and literate in a way that the vast majority of them would not have been in the absence of the intervention.

Our findings contain a few core messages. First, we show that offering this kind of an intervention at a near-free price to parents and children in two regions with extremely low learning and economic outcomes leads to a very high proportion of take-up. This suggests that supply constraints may be more important than demand constraints in understanding low 
educational outcomes in these and similar areas. Second, our results suggest there may be similarly large learning gains that can be realized by motivated donors or agencies through implementing a similar type of intervention in contexts where the status quo provider of education is either irregular or of extremely low quality.

This intervention achieved learning gains of unprecedented magnitude. While the intervention is much more highly-resourced than other interventions in this literature, a rough benefit-cost calculation suggests that, even using conservative assumptions, it is highly costefficient. This work, in conjunction with Eble et al. (2021), shows that the upper bound on the magnitude of intervention-driven learning gains in such deprived areas is much larger than previously thought. Finally, our study provides an opportunity to follow these children later in life, and learn about the longer-term economic and social returns to education, and literacy and numeracy more specifically, in a particularly poor region. This, we hope, will advance our understanding of two important phenomena: one, how best to help similar regions; and two, to quantify where, when, and how these basic skills can transform lives in the developing world. 


\section{References}

Angrist, Joshua D., Parag A. Pathak, and Christopher R. Walters. 2013. "Explaining Charter School Effectiveness.” American Economic Journal: Applied Economics 5 (4): 1-27.

Banerjee, Abhijit, Rukmini Banerji, James Berry, Esther Duflo, Harini Kannan, Shobhini Mukerji, Marc Shotland, and Michael Walton. 2017. "From Proof of Concept to Scalable Policies: Challenges and Solutions, with an Application." Journal of Economic Perspectives 31 (4): 73-102.

Banerjee, Abhijit, Esther Duflo, Nathanael Goldberg, Dean Karlan, Robert Osei, William Parienté, Jeremy Shapiro, Bram Thuysbaert, and Christopher Udry. 2015. "A Multifaceted Program Causes Lasting Progress for the Very Poor: Evidence from Six Countries." Science 348 (6236).

Becker, Gary S. 1994. Human Capital. Chicago: University of Chicago press.

Blimpo, Moussa P., David K. Evans, and Nathalie Lahire. 2011. "School-Based Management and Educational Outcomes: Lessons from a Randomized Field Experiment.” Unpublished Manuscript.

Bold, Tessa, Mwangi Kimenyi, Germano Mwabu, Alice Ng'ang'a, and Justin Sandefur. 2018. "Experimental Evidence on Scaling up Education Reforms in Kenya." Journal of Public Economics 168 (December): 1-20. https://doi.org/10.1016/j.jpubeco.2018.08.007.

Boone, Peter, Ila Fazzio, Kameshwari Jandhyala, Chitra Jayanty, Gangadhar Jayanty, Simon Johnson, Vimala Ramachandran, Filipa Silva, and Zhaoguo Zhan. 2014. "The Surprisingly Dire Situation of Children's Education in Rural West Africa: Results from the CREO Study in Guinea-Bissau (Comprehensive Review of Education Outcomes)." In African Successes, Volume II: Human Capital, 255-280. University of Chicago Press.

Bruhn, Miriam, and David McKenzie. 2009. "In Pursuit of Balance: Randomization in Practice in Development Field Experiments." American Economic Journal: Applied Economics, 200-232.

Burde, Dana, and Leigh L. Linden. 2012. "The Effect of Village-Based Schools: Evidence from a Randomized Controlled Trial in Afghanistan." Working Paper 18039. National Bureau of Economic Research. http://www.nber.org/papers/w18039.

Campbell, Frances A., and Craig T. Ramey. 1994. "Effects of Early Intervention on Intellectual and Academic Achievement: A Follow-up Study of Children from Low-Income Families." Child Development 65 (2): 684-698. . 1995. "Cognitive and School Outcomes for High-Risk African-American Students at Middle Adolescence: Positive Effects of Early Intervention." American Educational Research Journal 32 (4): 743-772.

Campbell, Marion K., Gilda Piaggio, Diana R. Elbourne, and Douglas G. Altman. 2012. "Consort 2010 Statement: Extension to Cluster Randomised Trials." BMJ 345: e5661.

Chabrier, Julia, Sarah Cohodes, and Philip Oreopoulos. 2016. "What Can We Learn from Charter School Lotteries?” Journal of Economic Perspectives 30 (3): 57-84.

Chaudhury, N., J. Hammer, M. Kremer, K. Muralidharan, and F. H. Rogers. 2006. "Missing in Action: Teacher and Health Worker Absence in Developing Countries." The Journal of Economic Perspectives 20 (1): 91-116.

Daun, Holger. 1997. "Teachers' Needs, Culturally-Significant Teacher Education and Educational Achievement in an African Context - the Case of Guinea-Bissau." International Journal of Educational Development 17 (1): 59-71. 
De Ree, Joppe, Karthik Muralidharan, Menno Pradhan, and Halsey Rogers. 2018. "Double for Nothing? Experimental Evidence on an Unconditional Teacher Salary Increase in Indonesia." Quarterly Journal of Economics 133 (2): 993-1039.

Dickson, Matt, and Colm Harmon. 2011. "Economic Returns to Education: What We Know, What We Don't Know, and Where We Are Going-Some Brief Pointers.” Economics of Education Review 30 (6): 1118-1122.

Dobbie, Will, and Roland G. Fryer Jr. 2013. "Getting beneath the Veil of Effective Schools: Evidence from New York City." American Economic Journal: Applied Economics 5 (4): 28-60.

Dubeck, Margaret M., and Amber Gove. 2015. "The Early Grade Reading Assessment (EGRA): Its Theoretical Foundation, Purpose, and Limitations." International Journal of Educational Development 40: 315-322.

Duflo, Esther. 2001. "Schooling and Labor Market Consequences of School Construction in Indonesia: Evidence from an Unusual Policy Experiment." American Economic Review 91 (4): 795-813.

Eble, Alex, Chris Frost, Alpha Camara, Baboucarr Bouy, Momodou Bah, Maitri Sivaraman, Jenny Hsieh, et al. 2021. "How Much Can We Remedy Very Low Learning Levels in Rural Parts of Low-Income Countries? Impact and Generalizability of a Multi-Pronged Para-Teacher Intervention from a Cluster-Randomized Trial in The Gambia." Journal of Development Economics 148:102539.

Evans, David K., and Anna Popova. 2016. "What Really Works to Improve Learning in Developing Countries? An Analysis of Divergent Findings in Systematic Reviews." The World Bank Research Observer 31 (2): 242-70. https://doi.org/10.1093/wbro/lkw004.

Glewwe, Paul, and Karthik Muralidharan. 2016. "Improving Education Outcomes in Developing Countries: Evidence, Knowledge Gaps, and Policy Implications.” In Handbook of the Economics of Education, 5:653-743. Amsterdam, Holland: Elsevier.

Heckman, James J., Seong Hyeok Moon, Rodrigo Pinto, Peter A. Savelyev, and Adam Yavitz. 2010. "The Rate of Return to the HighScope Perry Preschool Program." Journal of Public Economics 94 (1-2): 114-128.

Heckman, James J., and Stefano Mosso. 2014. "The Economics of Human Development and Social Mobility." Annu. Rev. Econ. 6 (1): 689-733.

Heckman, James, Rodrigo Pinto, and Peter Savelyev. 2013. "Understanding the Mechanisms through Which an Influential Early Childhood Program Boosted Adult Outcomes." American Economic Review 103 (6): 2052-86. https://doi.org/10.1257/aer.103.6.2052.

Hendren, Nathaniel, and Ben Sprung-Keyser. 2020. "A Unified Welfare Analysis of Government Policies." The Quarterly Journal of Economics 135 (3): 1209-1318.

Jordan, Nancy C., David Kaplan, Chaitanya Ramineni, and Maria N. Locuniak. 2009. "Early Math Matters: Kindergarten Number Competence and Later Mathematics Outcomes." Developmental Psychology 45 (3): 850.

Kremer, Michael, Conner Brannen, and Rachel Glennerster. 2013. "The Challenge of Education and Learning in the Developing World.” Science 340 (6130): 297-300.

Lakshminarayana, Rashmi, Alex Eble, Preetha Bhakta, Chris Frost, Peter Boone, Diana Elbourne, and Vera Mann. 2013. “The Support to Rural India's Public Education System (STRIPES) Trial: A Cluster Randomised Controlled Trial of Supplementary Teaching, Learning Material and Material Support.” PloS One 8 (7): e65775. 
Lee, David S. 2009. "Training, Wages, and Sample Selection: Estimating Sharp Bounds on Treatment Effects." The Review of Economic Studies 76 (3): 1071-1102.

Lepri, Jean-Pierre. 1988. "Formação de Professores, Locais, Materiais Escolares e Insucesso Escolar." Soronda: Revista de Estudos Guineenses 5: 83-102.

Levin, Henry M., Patrick J. McEwan, Clive Belfield, A. Brooks Bowden, and Robert Shand. 2017. Economic Evaluation in Education: Cost-Effectiveness and Benefit-Cost Analysis. SAGE publications.

List, John A., Azeem M. Shaikh, and Yang Xu. 2019. "Multiple Hypothesis Testing in Experimental Economics.” Experimental Economics 22 (4): 773-793.

Lochner, Lance, and Alexander Monge-Naranjo. 2012. "Credit Constraints in Education." Annual Review of Economics 4 (1): 225-256.

Mann, Vera, Ila Fazzio, Rebecca King, Polly Walker, Albino dos Santos, Jose Carlos de Sa, Chitra Jayanti, Chris Frost, Diana Elbourne, and Peter Boone. 2009. "The EPICS Trial: Enabling Parents to Increase Child Survival through the Introduction of CommunityBased Health Interventions in Rural Guinea Bissau." BMC Public Health 9 (1): 279.

Mbiti, Isaac, Karthik Muralidharan, Mauricio Romero, Youdi Schipper, Constantine Manda, and Rakesh Rajani. 2019. "Inputs, Incentives, and Complementarities in Education: Experimental Evidence from Tanzania*." The Quarterly Journal of Economics 134 (3): 1627-73. https://doi.org/10.1093/qje/qjz010.

McEwan, Patrick J. 2015. "Improving Learning in Primary Schools of Developing Countries: A Meta-Analysis of Randomized Experiments." Review of Educational Research 85 (3): 353-394.

Muralidharan, Karthik, Abhijeet Singh, and Alejandro Ganimian. 2019. "Disrupting Education? Experimental Evidence on Technology-Led Education in India." American Economic Review 109 (4): 1426-60.

Piper, Benjamin, Yasmin Sitabkhan, Jessica Mejía, and Kellie Betts. 2018. "Effectiveness of Teachers' Guides in the Global South: Scripting, Learning Outcomes, and Classroom Utilization. Occasional Paper. RTI Press Publication OP-0053-1805." RTI International.

Platas, L. M., L. Ketterlin-Gellar, A. Brombacher, and Y. Sitabkhan. 2014. "Early Grade Mathematics Assessment (EGMA) Toolkit.” RTI International, Research Triangle Park, $N C$.

Pratham. 2010. "Annual Status of Education Report (Rural) 2010.” http://www.pratham.org/aser08/ASER_2010_Report.pdf.

Pritchett, Lant. 2013. The Rebirth of Education: Schooling Ain't Learning. CGD Books. http://books.google.com/books?hl=en\&lr=\&id=PQ72AAAAQBAJ\&oi=fnd\&pg=PR1\&d $\mathrm{q}=$ pritchett+schooling+aint+learning\&ots $=$ uvSg4RtJhA\&sig=1jSzmH3E1 acmSrT3eRBD QCyjXwA.

Ray, Debraj, and Arthur Robson. 2018. "Certified Random: A New Order for Coauthorship." American Economic Review 108 (2): 489-520. https://doi.org/10.1257/aer.20161492.

Romero, Mauricio, Justin Sandefur, and Wayne Aaron Sandholtz. 2020. "Outsourcing Education: Experimental Evidence from Liberia.” American Economic Review 110 (2): 364-400.

RTI International. 2009. Early Grade Reading Assessment Toolkit.

—. 2017. "All Children Reading-Asia: EGRA Benchmarks and Standards Research Report.” 2017. https://shared.rti.org/content/all-children-reading-asia-egra-benchmarksand-standards-research-report. 
Sangreman, Carlos, Fátima Delgado, and Luis Vas Martins. 2018. “Guinea-Bissau (2014-2016). An Empirical Study of Economic and Social Human Rights in a Fragile State." Advances in Social Sciences Research Journal 5 (2).

Silva, Rui da, and Joana Oliveira. 2017. "40 Years of Educational Research in Guinea-Bissau: Mapping the Terrain." International Journal of Educational Development 57: 21-29.

Sprenger-Charolles, Liliane. 2008. "The Gambia : Early Grade Reading Assessment." World Bank Policy Report. https://openknowledge.worldbank.org/handle/10986/12972.

The World Bank. 2019. "Economic Data on Guinea Bissau" Website, accessed October 28, 2019. URL:

https://data.worldbank.org/indicator/NY.GDP.MKTP.KD.ZG?locations=GW.

USAID. 2019. "About EGRA: Early Grade Reading Assessment.” 2019. https://www.earlygradereadingbarometer.org/pages/about_egra.

Woessmann, Ludger. 2016. "The Importance of School Systems: Evidence from International Differences in Student Achievement.” Journal of Economic Perspectives 30 (3): 3-32. 


\section{Appendix}

\section{Table A.1. Power calculation}

\begin{tabular}{ccccc}
\hline $\begin{array}{c}\text { Allocation ratio } \\
\text { intervention: } \\
\text { control }\end{array}$ & $\begin{array}{c}\text { Loss to } \\
\text { follow-up }\end{array}$ & $\begin{array}{c}\text { Average no. of } \\
\text { children per } \\
\text { cluster after loss to } \\
\text { follow-up* }\end{array}$ & $\begin{array}{c}\text { Minimum difference to detect } \\
(\%)\end{array}$ \\
\cline { 4 - 5 } $1: 1$ & $17 \%$ & 35 & $\mathbf{2 0}$ & $\mathbf{2 5}$ \\
\hline \multirow{2}{*}{$1: 2$} & $25 \%$ & 32 & 80 & 94 \\
\hline $17 \%$ & 35 & 75 & 95 \\
\hline
\end{tabular}

Table A.1 notes: Power obtained with a two-sided 5\% level test with 49 clusters total, assuming an Intracluster Coefficient $=0.03 .{ }^{*}$ : the assumed average number of children per cluster before loss to follow up is 43 . 


\section{Table A.2. Description of subtasks}

\begin{tabular}{|c|c|}
\hline EGRA & EGMA \\
\hline 1: Read a letter's sound (e.g., “oh” for o) & 1: Read a number (e.g., 2, 9, 45) \\
\hline $\begin{array}{l}\text { 2: Differentiate sounds (e.g., which word starts with a } \\
\text { different sound: casa, livro, or cama) }\end{array}$ & 2: Choose the larger number (e.g., 7 or 5 ) \\
\hline 3: Read a made-up word (e.g., tila) & 3: Complete a sequence (e.g., $141516 \_$_ ) \\
\hline \multirow[t]{2}{*}{ 4: Read a familiar (Portuguese) word (e.g., sol) } & 4a: Simple addition (e.g., 1+3) \\
\hline & 4b: Two-digit addition (e.g., 14+25) \\
\hline 5a: Read a short passage & 5a: Simple subtraction (e.g., 5-2) \\
\hline 5b: Answer questions on the passage's content & 5b: Two-digit subtraction (e.g., 26-14) \\
\hline $\begin{array}{l}\text { 6: Listen to a different short passage, answer questions } \\
\text { on the passage's content }\end{array}$ & 6: Solve a simple word problem read aloud \\
\hline
\end{tabular}

Table A.2 notes: this table provides descriptions of the different types of questions asked on the reading (EGRA) and math (EGMA) tests, respectively. These are referred to as "tasks" or "subtasks", by the number given in this table. 


\section{Table A.3. Attendance of enrolled children in intervention classes}

\begin{tabular}{|c|c|}
\hline & $\begin{array}{c}\text { (1) } \\
\text { Attendance (N) }\end{array}$ \\
\hline Mean & $85.72 \%$ \\
\hline SD & $30.80 \%$ \\
\hline \multicolumn{2}{|l|}{ Distribution of attendance } \\
\hline $0 \%$ of classes & $9.27 \%(60)$ \\
\hline$>0$ to $25 \%$ of classes & $1.24 \%(8)$ \\
\hline$>25 \%$ to $50 \%$ of classes & $2.32 \%(15)$ \\
\hline$>50 \%$ to $75 \%$ of classes & $2.01 \%(13)$ \\
\hline$>75 \%$ to $100 \%$ of classes & $85.16 \%(551)$ \\
\hline Missing data & $0.31 \%(2)$ \\
\hline $\begin{array}{l}\text { Number of non-missing } \\
\text { observations }\end{array}$ & 647 \\
\hline
\end{tabular}

Table A.3 notes: this table shows the average attendance of children in the intervention arm at intervention classes, as a proportion of total classes held. The number of observations corresponding to these proportions are given in parentheses. 
Table A.4. Heterogeneity of effect by village school traits

\begin{tabular}{|c|c|c|c|c|}
\hline Group & $\begin{array}{c}\text { (1) } \\
\text { Intervention } \\
\text { (SD) }\end{array}$ & $\begin{array}{c}\text { (2) } \\
\text { Control } \\
\text { (SD) }\end{array}$ & $\begin{array}{c}\text { (3) } \\
\text { Adjusted } \\
\text { difference } \\
(\mathrm{SE}) \\
\end{array}$ & $\begin{array}{c}(4) \\
\text { p-value }\end{array}$ \\
\hline \multicolumn{5}{|c|}{ Highest grade taught in village } \\
\hline $\begin{array}{l}\text { Third or fourth grade } \\
(\mathrm{N}: \mathrm{I}=337, \mathrm{C}=459)\end{array}$ & $\begin{array}{l}71.34 \\
(15.24)\end{array}$ & $\begin{array}{l}12.60 \\
(12.06)\end{array}$ & $\begin{array}{l}57.71 \\
(0.92)\end{array}$ & \multirow[t]{2}{*}{0.77} \\
\hline $\begin{array}{l}\text { Fifth grade or higher } \\
\mathrm{C} \cdot \mathrm{I}=226 \mathrm{C}=607)\end{array}$ & $\begin{array}{c}69.20 \\
(15.45)\end{array}$ & $\begin{array}{l}10.32 \\
(9.95)\end{array}$ & $\begin{array}{c}58.1 \\
(0.98)\end{array}$ & \\
\hline \multicolumn{5}{|c|}{ Total number of teachers in village } \\
\hline One or two teachers & 69.38 & 10.89 & 58.08 & \multirow[t]{4}{*}{0.19} \\
\hline$(\mathrm{N}: \mathrm{I}=393, \mathrm{C}=932)$ & (14.73) & $(10.35)$ & $(0.75)$ & \\
\hline Three or four teachers & 73.03 & 14.16 & 55.86 & \\
\hline$(\mathrm{N}: \mathrm{I}=170, \mathrm{C}=134)$ & $(16.44)$ & $(14.27)$ & $(1.53)$ & \\
\hline \multicolumn{5}{|c|}{ Lowest quality material of school roof } \\
\hline Roof is natural & 72.51 & 13.60 & 57.73 & \multirow[t]{4}{*}{0.80} \\
\hline$(\mathrm{N}: \mathrm{I}=122, \mathrm{C}=48)$ & (13.53) & $(12.01)$ & $(0.73)$ & \\
\hline Roof is synthetic & 69.92 & 11.2 & 58.29 & \\
\hline$(\mathrm{N}: \mathrm{I}=441, \mathrm{C}=1018)$ & $(15.78)$ & $(10.90)$ & $(2.13)$ & \\
\hline \multicolumn{5}{|c|}{ Presence of public school in village } \\
\hline No public school in village & 67.94 & 12.04 & 56.77 & \multirow[t]{4}{*}{0.21} \\
\hline$(\mathrm{N}: \mathrm{I}=179, \mathrm{C}=284)$ & $(15.89)$ & $(11.31)$ & $(1.21)$ & \\
\hline Public school in village & 71.66 & 11.04 & 58.67 & \\
\hline$(\mathrm{N}: \mathrm{I}=384, \mathrm{C}=782)$ & $(14.96)$ & $(10.83)$ & $(0.87)$ & \\
\hline \multicolumn{5}{|c|}{ Presence of community school in village } \\
\hline No community school in village & 69.62 & 11.05 & 57.86 & \multirow[t]{4}{*}{0.91} \\
\hline$(\mathrm{N}: \mathrm{I}=416, \mathrm{C}=892)$ & $(14.62)$ & $(10.47)$ & $(0.75)$ & \\
\hline Community school in village & 72.91 & 12.61 & 57.69 & \\
\hline$(\mathrm{N}: \mathrm{I}=147, \mathrm{C}=174)$ & $(17.05)$ & $(13.16)$ & $(1.46)$ & \\
\hline
\end{tabular}

Table A.4 notes: this table shows exploratory estimates of heterogeneity in the effect of the intervention on composite test scores by the characteristics of the schools in the village, following the convention of Table 7 . There is only one village in our study which does not have a school in the village, and we exclude it from this analysis. 
Table A.5. Sibling enrollment in school

\begin{tabular}{lcccc}
\hline \hline Group & $\begin{array}{c}\mathbf{( 1 )} \\
\text { Intervention } \\
\text { (SD) }\end{array}$ & $\begin{array}{c}\text { (2) } \\
\text { Control } \\
\text { (SD) }\end{array}$ & $\begin{array}{c}\text { (3) } \\
\text { Adjusted } \\
\text { difference } \\
\text { (SE) }\end{array}$ & $\begin{array}{c}\text { (4) } \\
\text { p-value }\end{array}$ \\
\hline Older sibling enrolled in school & 0.892 & 0.923 & -0.050 & 0.023 \\
(N: I=269, C=521) & $(0.311)$ & $(0.266)$ & $(0.022)$ & \\
Younger sibling enrolled in school & 0.636 & 0.556 & 0.013 & 0.777 \\
(N: I=176, C=363) & $(0.482)$ & $(0.497)$ & $(0.046)$ & \\
\hline \hline
\end{tabular}

Table A.5 notes: this table shows the levels of enrollment of the child's next-younger and next-older siblings in school, and tests for differences across treatment group, following the convention of Table 4. 
Figure A.1. Map of Guinea Bissau and study area

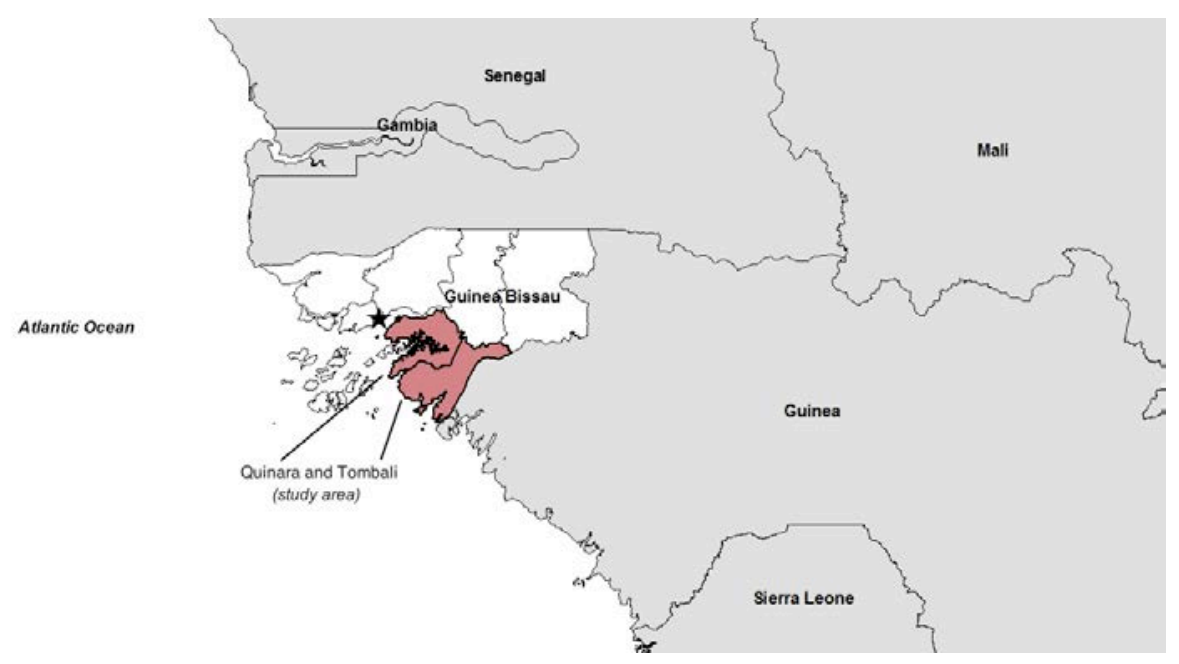

Figure A.1 notes: this figure shows a map of Guinea Bissau and surrounding countries, with the regions of Guinea Bissau with thinner lines, and the two study regions shaded in red and labeled. 


\section{Figure A.2. CONSORT-style diagram of flow of participants through the study}

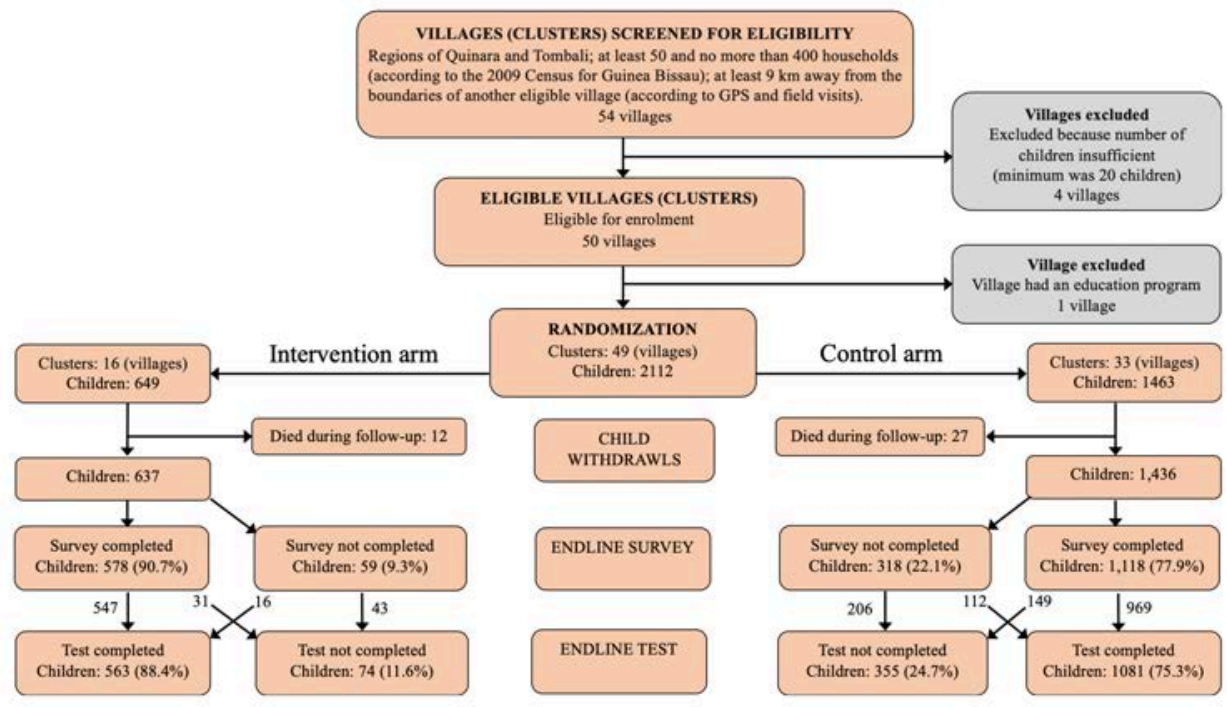

Figure A.2 notes: this figure shows how participants (villages and children) flowed through the trial, from screening for eligibility to participation in the endline survey and test. 


\section{Figure A.3. Attendance in school: number of days missed in last two weeks}

Panel A: Data from midline (2015)

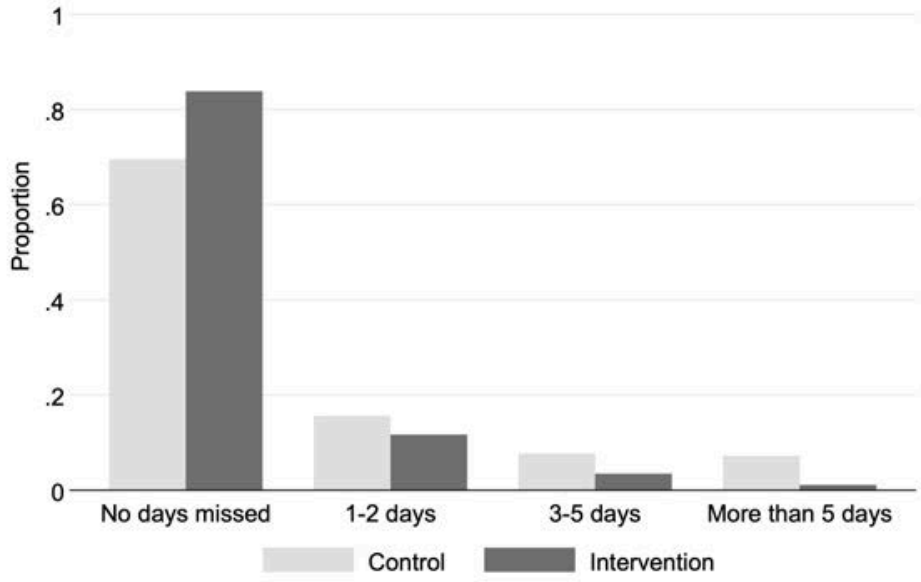

Panel B: Data from endline (2017)

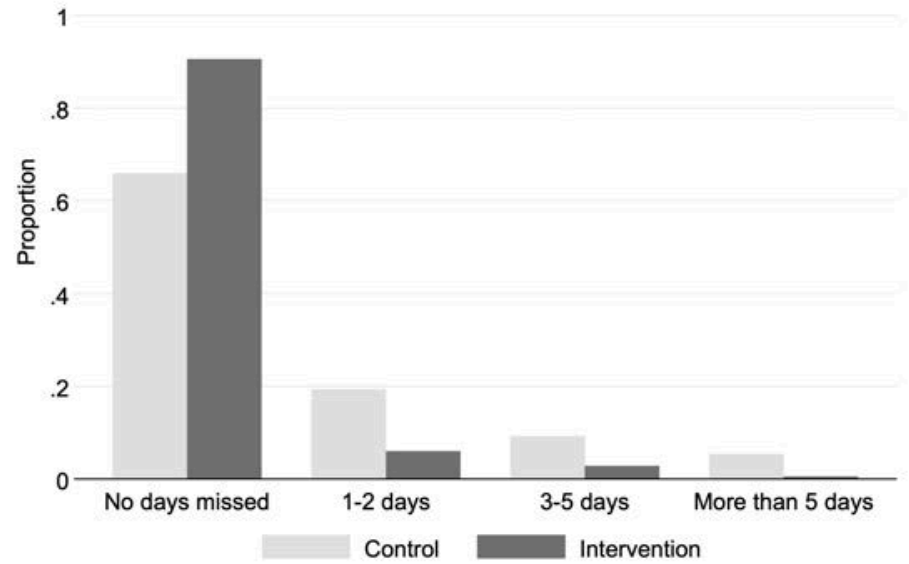

Figure A.3 notes: This figure shows parents' report of how many days their child missed school in the two weeks prior to being interviewed, separately at the midline and at the endline surveys (in Panels A and B, respectively), and separately by randomization group. We present results only for those children who were enrolled in school at the time of survey. A simple chi-square test rejects the null of no relationship between attendance and intervention status, with $\mathrm{p}<0.001$ in both panels. 


\section{Figure A.4. Sibling literacy and numeracy tests}

Younger sibling

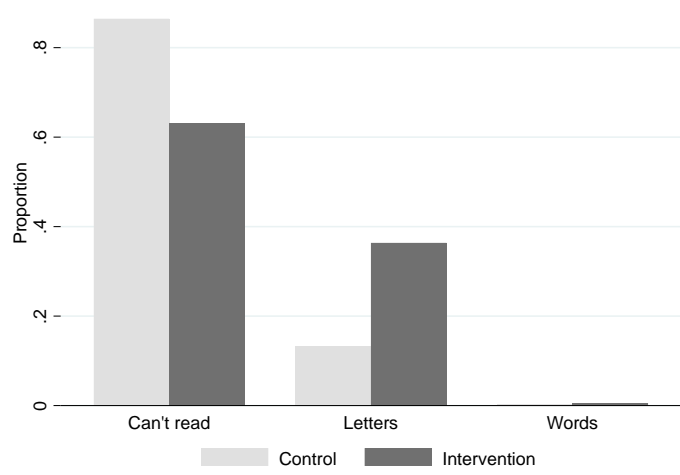

Older sibling

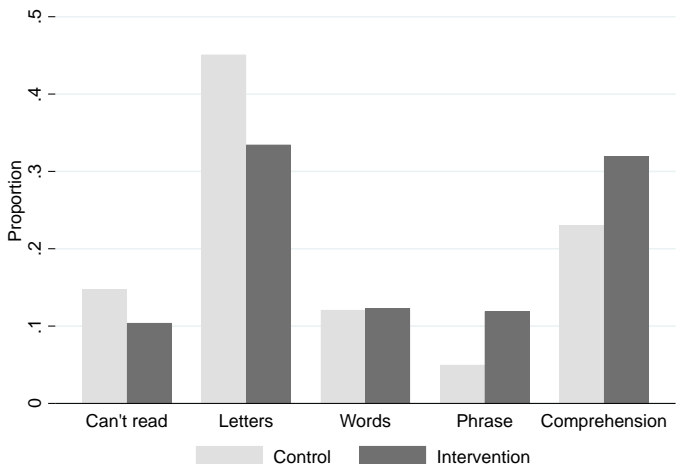

Panel A: Literacy
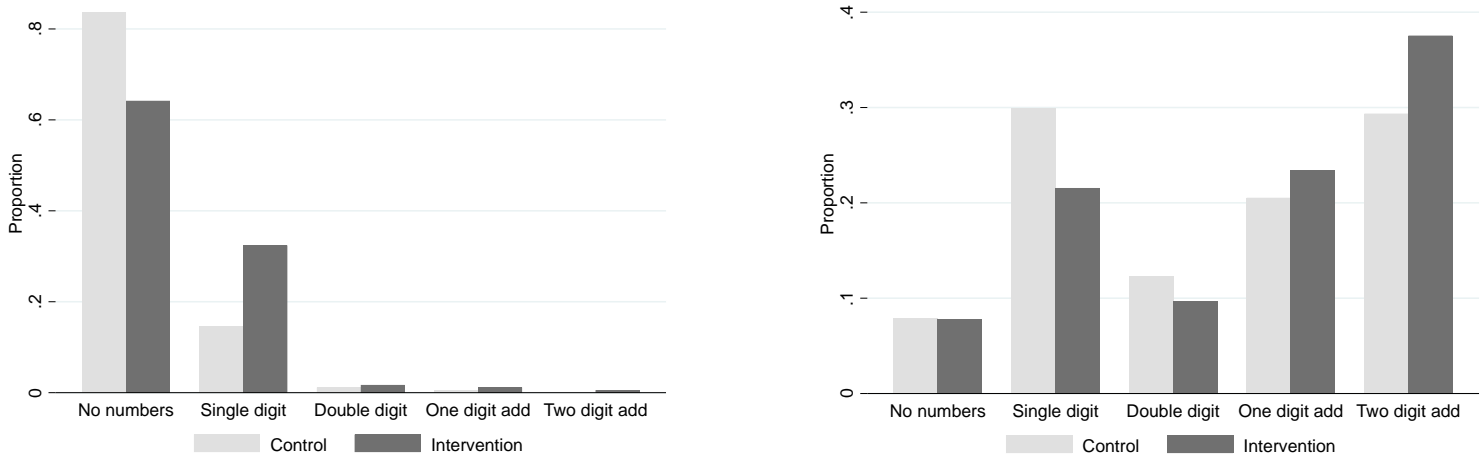

Panel B: Numeracy

Figure A.4 notes: This figure shows the results of the sibling literacy and numeracy tests administered at the endline for students present in the survey who also had siblings present in the village at the time of the endline survey. There were 362 younger siblings and 521 older siblings found in the control villages, and 176 younger siblings and 269 older siblings in the intervention villages. A simple chi-square test rejects the null of no relationship between literacy and intervention status, with $\mathrm{p}<0.001$ in both panels. It rejects the null of no relationship between numeracy and intervention status with $\mathrm{p}=0.040$ for older siblings, and $\mathrm{p}<0.001$ for younger siblings. 
Electronic appendix (for online publication only)

\section{Contents:}

A. Further description of disruption to implementation of the para teacher model B. Test papers 


\section{Appendix A: Further description of disruption to implementation of the para teacher model}

We began discussions with the government about an education research project in 2011, after the completion of the data collection for Boone et al. (2014). We originally agreed with the government on an experiment in which we would open dozens of academic centers where we would deliver our curriculum. For training, we recruited 100 candidates with at least a high school education, but no teacher qualifications. Our plan was that, at the end of the training, we would select as many final candidates from this group as were qualified for implementation of our intervention and, as described in Section 2, run a para teacher intervention as part of a larger effort to evaluate that model's scalability and generalizability.

We hired Portuguese-language and teacher training professionals to travel to GuineaBissau and train our candidates for one year. During the training, candidates were paid a living stipend and, as part of the training, they received Portuguese language proficiency certification from an international organization and a pedagogy certification from the Guinea Bissau Ministry of Education. In return, they provided a written agreement that after the training, should they be selected, they would commit to residing in the villages we assigned them in Quinara and Tombali and working as teachers there for at least one year.

At the end of the year of training, we selected 48 of the 100 candidates to serve as teachers. Prior to the start of implementation, these individuals reneged on their commitment, refusing to work under the previously agreed-upon employment conditions. They formally submitted a new set of demands, including the salary increase described in the introduction and the removal of the initial probationary period of employment we had agreed upon in order to 
remove low-performing teachers. We were not in a position to accept these demands and refused. Guinea Bissau's government supported us in the dispute, but the teachers attempted to litigate in the country's courts and the resolution of this took several months. As described in Section 2, this led us to change the focus of the intervention to one in which we hired trained teachers, as opposed to para teachers, which also consisted of a change in the research question asked by the study. 
Appendix B: EGRA and EGMA test papers used in endline test

(tests begin on next page) 
Teste de Leitura em língua portuguesa para os primeiros anos de ensino na Guiné-Bissau: Formulário de Instruções para os Enumeradores e Respostas dos alunos

Portuguese Early Grade Reading Assessment in Guinea-Bissau: Instructions for Enumerators and Children Response Form

\section{PORTUGUÊS Portuguese}

Instruções Gerais

É importante estabelecer uma relação descontraída e de confiança com a criança que vai ser avaliada através de uma conversa inicial com questões de interesse para a criança (ver exemplo abaixo). Aproveite este momento para identificar qual a língua em que a criança se sente mais confortável. A criança deve ver este exercício mais como um jogo do que uma avaliação. É importante que leia SOMENTE em voz alta o texto que está a negrito, de forma calma e clara, para que a criança possa compreender os exercícios. It is important to establish a playful and relaxed relationship with the child that will be assessed through an initial talk on topics of interest to the child (see example below). Use this time to identify in what language the child is most comfortable with. The child should perceive the assessment more as a game rather than an evaluation. It is important that you ONLY read aloud the text in bold, slowly and clearly, so that the child can understand the exercises.

¿ Bom dia. 0 meu nome é_____ e trabalho para a Effective Intervention. E tu, como te chamas? Como está a tua família? Quando eu não estou a trabalhar, eu gosto muito de . E tu, o que mais gostas de fazer quando não estás na escola?

Good morning. My name is__ and I work at Effective Intervention. And you, what's your name? How is your family? When I am not at work, I like to And you? What do you most enjoy doing when you are not at school?

\section{Consentimento Verbal}

- Vou-te explicar porque é que eu hoje estou aqui. Eu trabalho para um projecto da Effective Intervention. Viemos à tua escola fazer um trabalho para compreendermos melhor como é que as crianças aprendem a ler e matemática e tu foste escolhido para nos ajudares. Let me tell you why I am here today. I am working with a project of Effective Intervention. We came today to your school to do an exercise to help us better understand how children learn how to read and do mathematics, and you were chosen to help us.

- Gostaríamos de pedir a tua ajuda. Mas não tens de participar se não quiseres. We would like to ask for your help. But you do not have to take part if you do not want to.

- Vamos fazer um jogo de leitura e matemática. Eu vou pedir-te para leres em voz alta algumas letras, palavras e pequenas histórias. Depois irás ter com o meu colega (aponte na direcção do enumerador de EGMA), e ele/ela vai-te pedir para identificares números, fazeres contas e resolveres alguns problemas. We are going to play reading and mathematics games. I am going to ask you to read letters, words and a short story out loud. Then you will go to my friend/colleague sitting at the other side (point to the direction of the EGMA enumerator), and he/she will ask you to identify numbers, do some calculations and solve a few problems.

- Por vezes vou utilizar este relógio para saber quanto tempo demoras a completar algumas tarefas. Se ouvires um som, não prestes atenção. Sometimes I will use this timer to time how long it takes you to complete some of the tasks. If you hear it beeps, please do not pay attention to it.

- Este exercício NÃO é uma ficha de avaliação e não vai influenciar as tuas notas da escola. This is NOT a test and it will not affect your grade at school.

- Relembro que não tens de participar se não quiseres. Depois de começarmos, se preferires não responder a uma das perguntas, não há problema. Once again, you do not

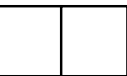


have to participate if you do not wish to. Once we begin, if you would rather not answer a question, that's all right.

- Podemos começar? [Espere até a criança responder] Can we start? (wait until the child replies)

Se o consentimento verbal é obtido, marque a caixa:

SIM

If the oral consent is obtained, please tick: $\square$ YES

Se o consentimento verbal não for obtido, marque na lista de alunos.

If the oral consent is not obtained, please make a note on the student list.

\begin{tabular}{|c|c|c|c|}
\hline A. Data: Date: & $\mathrm{c} / \mathrm{dd} / \mathrm{mm} /$ aaaa $)$ & $\begin{array}{l}\text { F. Género do Aluno: } \\
\text { Child Gender: }\end{array}$ & $\begin{array}{l}\square \text { 1. Fem } \\
\square \text { 2.Masc }\end{array}$ \\
\hline $\begin{array}{l}\text { B. Hora Início: } \\
\text { Assessment start time: }\end{array}$ & ${ }_{-} \mathrm{h} \_\mathrm{m}$ & $\begin{array}{l}\text { G. Nome da Escola } \\
\text { que a criança } \\
\text { frequenta: Name of } \\
\text { School the child attends: }\end{array}$ & $\begin{array}{l}\text { A criança não } \\
\text { frequenta este ano a } \\
\text { escola. The child is not } \\
\text { attending school this } \\
\text { school year }\end{array}$ \\
\hline $\begin{array}{l}\text { C. Code of } \\
\text { Enumerador: Code of } \\
\text { Enumerator: }\end{array}$ & & $\begin{array}{l}\text { H. Código da Escola: } \\
\text { Code of School: }\end{array}$ & \\
\hline $\begin{array}{l}\text { D. Nome da Criança: } \\
\text { Name of child: }\end{array}$ & & $\begin{array}{l}\text { F. Turno (marque a } \\
\text { opção aplicável): } \\
\text { School shift (tick as } \\
\text { appropriate): }\end{array}$ & $\begin{array}{l}\square \text { 1. Manhã: } \\
\text { Morning } \\
\square \text { 2. Tarde: } \\
\text { Afternoon }\end{array}$ \\
\hline $\begin{array}{l}\text { E. Código da Criança } \\
\text { Code of child: }\end{array}$ & & $\begin{array}{l}\text { I. Centro de } \\
\text { Avaliação: Assessment } \\
\text { centre: }\end{array}$ & \\
\hline
\end{tabular}

\section{TAREFA 1. IDENTIFICAR O NOME DAS LETRAS}

TASK 1. Letter name Identification

- Nesta folha estão escritas letras do alfabeto. Por favor, lê as letras que estão escritas nesta folha.

On this page there are written letters of the alphabet. Please read the letters on this page.

[Aponte para "J"] [Point to "J"]. Por exemplo, esta letra é “J". For example, this letter is " $\mathrm{J}$ ".

[Aponte para " $n$ "] [Point to " $n$ "] Vamos praticar. Diz-me qual é esta letra. Let's practice. Tell me what letter this is.

$\checkmark \_$[Se a criança respondeu " $n$ ", diga] Muito bem, esta letra é o " $n$ ". [If the child answered $n$, say] Very good, this letter is " $n$ ".

$\boldsymbol{x} \mathbf{2}$ [Se a criança não respondeu " $n$ ", diga] Esta letra é "n". [If the child has not answered " $n$ ", say] This letter is " $n$ ".

[Aponte para " $X$ "] [Point to " $X$ "]. Agora vamos experimentar outra. Diz-me que letra é esta. Now let's try another one. Tell me what letter this is.

$\checkmark$ [Se a criança respondeu "X", diga] Muito bem, esta letra é " $x$ " If the child answered " $X$ ", say] Very good, this letter is " $X$ ".
60 segundos / 60 seconds

Inicie o cronómetro assim que a criança lê a primeira letra. Pare o cronómetro assim que a criança lê a ultima letra. Start the timer when the child reads the first letter. Stop the timer when the child reads the last letter.

- Se a criança hesitar numa letra mais de 3 SEGUNDOS, leia a letra e depois aponte para a letra 
[Se a criança não respondeu " $X$ ", diga] Esta letra é " $x$ ". [If the child has not answered " $X$ ", say] This letter is " $x$ ".

[Aponte para a primeira letra na linha depois do exemplo]. [Point to the first letter on the line just after the example] Percebeste o que vamos fazer? Quando eu disser "começar", começas a aqui, lê ao longo da página [aponte] o melhor que souberes. Aponta para cada letra que lês e lê em voz alta. Lê o mais depressa e correctamente que conseguires. Se houver uma letra que não conheces, passa para a letra seguinte. Have you understood? When I say "start", start reading and begin here, read across the page [point] the best you can. Point to each letter you read and read in a loud voice. Read as quickly and carefully as you can. If you come across a letter you do not know, just go on to the next letter.

Coloca o teu dedo na primeira letra [confira que a criança o faz]. Estás pronto?

Podes começar. Put your finger on the first letter (make sure the child does so). Ready? Let's start.

L ( / ) Marque as letras incorrectas com uma barra. Mark any incorrect words with a slash (/).

(ø) Marque com um círculo as autocorrecções se já marcou uma letra incorrecta. Mark with a circle the self-corrections if you already marked as incorrect.

( ] ) Marque a última letra lida com um parênteses recto. Mark the final word read with a bracket (]).

Exemplos: J $\mathrm{n} X$

\begin{tabular}{|c|c|c|c|c|c|c|c|c|c|}
\hline & 2 & 3 & 4 & 5 & 6 & 7 & 8 & 9 & 10 \\
\hline S & i & h & R & B & p & E & o & n & t \\
\hline L & E & t & d & A & t & a & D & e & N \\
\hline h & O & E & M & u & r & L & G & R & U \\
\hline g & r & b & e & v & f & m & T & S & R \\
\hline t & S & q & A & M & c & O & t & N & P \\
\hline E & A & e & S & o & F & h & U & a & T \\
\hline R & g & H & b & S & i & g & m & J & L \\
\hline L & V & n & O & e & o & E & r & p & x \\
\hline S & t & C & n & p & A & F & c & a & E \\
\hline n & A & c & D & d & Q & O & j & E & n \\
\hline
\end{tabular}

Tempo restante no cronómetro no momento em que terminou (SEGUNDOS). Time remaining on stopwatch at completion (SECONDS)

Exercício descontinuado porque a criança não disse nenhuma letra correcta na primeira linha. Exercise discontinued because the child had no correct answers in the first line

$N A$ :

$N E$ : seguinte e diga

"Continua".

Marque a letra que leu como

incorrecta. If the child hesitates for 3 seconds, read that letter and then point to the next letter and say "Continue". Mark the letter you read as incorrect.

Muando o cronómetro chegar a zero, diga "pára". When the timer reaches 0 , say "stop."

Me a criança não deu nenhuma resposta correcta na primeira linha, diga "Muito

Obrigado", pare o exercício, marque no quadro abaixo e passe para o próximo exercício. If the child does not provide a single correct response on the first line, say "Thank you!", discontinue this subtask, check the box at the bottom, and go on to the next subtask. 
Obrigada, vamos passar para o exercício seguinte. Thank you, let's move to the next task.

\section{TAREFA 2. IDENTIFICAR O SOM INICIAL \\ - Neste exercício deves ouvir as palavras que eu vou ler. Eu vou ler três palavras e uma delas começa com um som diferente. Diz-me que palavra começa com um som diferente. In this exercise, you will listen to the words that I read. I will read three words and one of them starts with a different sound. Tell me which one starts with a different sound.}

Por exemplo: For example:

bota, bola, sapo, qual começa com um som diferente? bota, bola, sapo, which one starts with a different sound?

[Se a criança respondeu "sapo", diga] Muito bem, "sapo" começa com um som diferente. [If the child answered "sapo", say] Very good, "sapo" starts with a different sound.

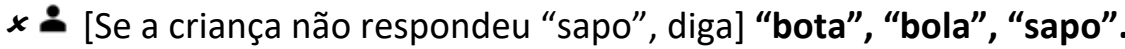
"sapo" começa com um som diferente do que "bota" e "bola". [If the child did not answer "sapo", say] "bota", "bola", "sapo". "sapo" starts with a different sound than "bota" and "bola".

Agora vamos experimentar outra vez: Now let's try agin:

casa, livro, cama, qual começa com um som diferente? casa, livro, cama which one starts with a different sound?

[Se a criança respondeu "livro", diga] Muito bem, "livro" começa com um som diferente. [If the child answered "livro", say] Very good, "livro" starts with a different sound.

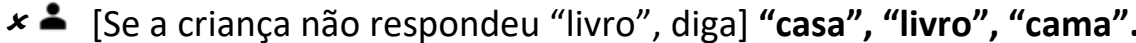
"livro" começa com um som diferente do que "casa" e "camisa". [If the child did not answer "livro", say] "casa", "livro", "cama". "livro" starts with a different sound than "casa" and "cama".

Compreendeste? Estás pronto? Vamos começar. Did you understand? Are you ready? Let's start.

es $(\checkmark) 1=$ Correcto Correct

$(\checkmark) 0=$ Incorrecto Incorrect

$(\checkmark)$. = Sem resposta No answer
Se a criança não responder os primeiros 5 itens, diga "Obrigado", pare o exercício, marque no quadro abaixo e passe para o próximo exercício. If the child does not provide an answer in the first 5 items, say "Thank you!", discontinue this subtask, check the box at the bottom, and go on to the next subtask.

- Se a criança hesitar num item mais de 5 SEGUNDOS, diga a resposta. Marque o item que mencionou como "Sem resposta". If the child hesitates for 5 seconds, provide the answer. Mark the item that you provided answer as "no response".

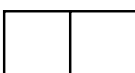




\begin{tabular}{|l|c|c|c|c|c|c|c|}
\hline & & & Resposta & Correcto & Incorrecto & $\begin{array}{c}\text { Sem } \\
\text { resposta }\end{array}$ \\
\hline 1. & lápis & cama & lenha & [cama] & 1 & 0 &. \\
\hline 2. & mota & mola & dedo & [dedo] & 1 & 0 &. \\
\hline 3. & salto & rato & roda & [salto] & 1 & 0 &. \\
\hline 4. & manga & vaso & mola & [vaso] & 1 & 0 &. \\
\hline 5. & sala & banco & saia & [banco] & 1 & 0 &. \\
\hline 6. & boca & bebé & tambor & [tambor] & 1 & 0 &. \\
\hline 7. & copo & tenda & tecto & [copo] & 1 & 0 &. \\
\hline 8. & vaca & fome & fumo & [vaca] & 1 & 0 &. \\
\hline 9. & carvão & planta & pedra & [carvão] & 1 & 0 &. \\
\hline 10. & pato & poço & tinta & [tinta] & 1 & 0 &. \\
\hline
\end{tabular}

Obrigada, vamos passar para o exercício seguinte. Thank you, let's move to the next task.

\section{TAREFA 3. LER PALAVRAS INVENTADAS Invented word Reading \\ - Nesta folha estão escritas palavras inventadas. Gostava que lesses o máximo de palavras que conseguires. Não deves soletrar, mas sim ler as palavras. In this sheet there are some made-up words. I would like you to read as many as you can. Do not spell the words, but read them.}

[Aponte para a palavra "leto"] Por exemplo, esta palavra inventada é "leto". [Point to the word "leto"] For example this made up word is "leto".

[Aponte para "difa"] Vamos praticar. Lê esta palavra.

[Point to the word "difa"] Let's practice. Read this word.

[Se a criança respondeu "difa", diga] Muito bem, esta palavra inventada é "difa". [If the child answered "difa", say] Very good, this made up word is "difa".

$\boldsymbol{x} \mathbf{\bullet}$ [Se a criança não respondeu "difa", diga] Esta palavra inventada é "difa". [lf the child did not answer "difa", say]This made up word is "difa".

[Aponte para a palavra "maba"] Agora vamos experimentar outra. Lê esta palavra. [Point to the word "maba"] Now let's try another one. Read this word.

[Se a criança respondeu "maba", diga] Muito bem, esta palavra inventada é "maba". [If the child answered "maba", say] Very good, this made up word is "maba".

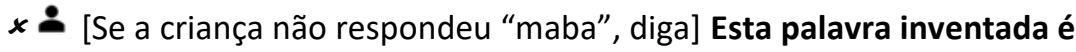
"maba". [lf the child did not answer "maba", say] This made up word is "maba".
60 segundos 60 seconds

Inicie o cronómetro assim que a criança lê a primeira palavra. Pare o cronómetro assim que a criança lê a última palavra. Start the timer when the child reads the first word. Stop the timer when the child reads the last word.

O Se a criança hesitar ou parar numa palavra mais de 3 SEGUNDOS, diga a palavra, aponte para a próxima palavra e diga 
[Aponte para a primeira palavra "bó"] Quando eu disser "começar", começa aqui [aponte para a primeira palavra], e lê ao longo da página [aponte]. Aponta para cada palavra e lê em voz alta. Lê o mais depressa e o melhor que puderes. Se houver uma palavra que não consigas ler, passa para a palavra seguinte.

Coloca o teu dedo na primeira palavra [confirmar que a criança coloco ao dedo]. Estás pronto? Podes começar. [Point to the word "bó"]. When I say "start", start here [point to the first word], and read through the page [point]. Point to each word and read out loud. Read as fast and the best you can. If there is one word you can't read, move to the next one. Put your finger in the first one [make sure the child does so]. Are you ready? You can start.

( / ) Marque as palavras incorrectas com uma barra. Mark any incorrect words with a slash (/).

(ø) Marque com um círculo as autocorrecções se já marcou uma palavra incorrecta. Mark with a circle the self-corrections if you already marked as incorrect.

( ] ) Marque a última letra lida com um parenteses recto. Mark the final word read with a bracket (]).

Exemplos: leto difa maba

\begin{tabular}{|c|c|c|c|c|}
\hline \multicolumn{1}{c}{1} & \multicolumn{2}{c}{3} & \multicolumn{2}{c}{5} \\
\hline bó & tila & lum & poa & hove \\
\hline leta & ezal & rou & bunfe & pafa \\
\hline pil & fó & chuda & orpa & nusa \\
\hline gava & zala & lorta & dasa & lora \\
\hline dalu & himo & enha & nabel & saliz \\
\hline mesca & vesta & hodem & muide & nalha \\
\hline teça & pajam & darca & orpão & dação \\
\hline dalé & igua & seva & jile & gamola \\
\hline bavai & bleta & coeta & foxe & vono \\
\hline gorão & leço & golca & jalno & cefo \\
\hline
\end{tabular}

"Continua".

Marque a palavra que leu como incorrecta. If the child hesitates for 3 seconds, say the word and then point to the next word and say "Continue". Mark the word that you provided as incorrect.

m Quando o cronómetro chegar a zero, diga "pára". When the timer reaches 0 , say "stop."

Me a criança não conseguiu ler nenhuma palavra correctamente na primeira linha ( 5 palavras), diga "Obrigado", pare o exercício, marque no quadro abaixo e passe para o próximo exercício. If the child does not provide a single correct response in the first line (5 words), say "Thank you!", discontinue this subtask, check the box at the bottom, and go on to the next subtask.

Tempo restante no cronómetro no momento em que terminou (SEGUNDOS). Time remaining on stopwatch at completion (SECONDS)

Exercício descontinuado porque a criança não disse nenhuma palavra correcta na primeira linha. Exercise discontinued because the child had no correct answers in the first line

\begin{tabular}{l|l} 
NA: & $N E:$
\end{tabular}

Obrigada, vamos passar para o exercício seguinte. Thank you, let's move to the next task.

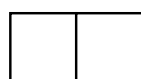




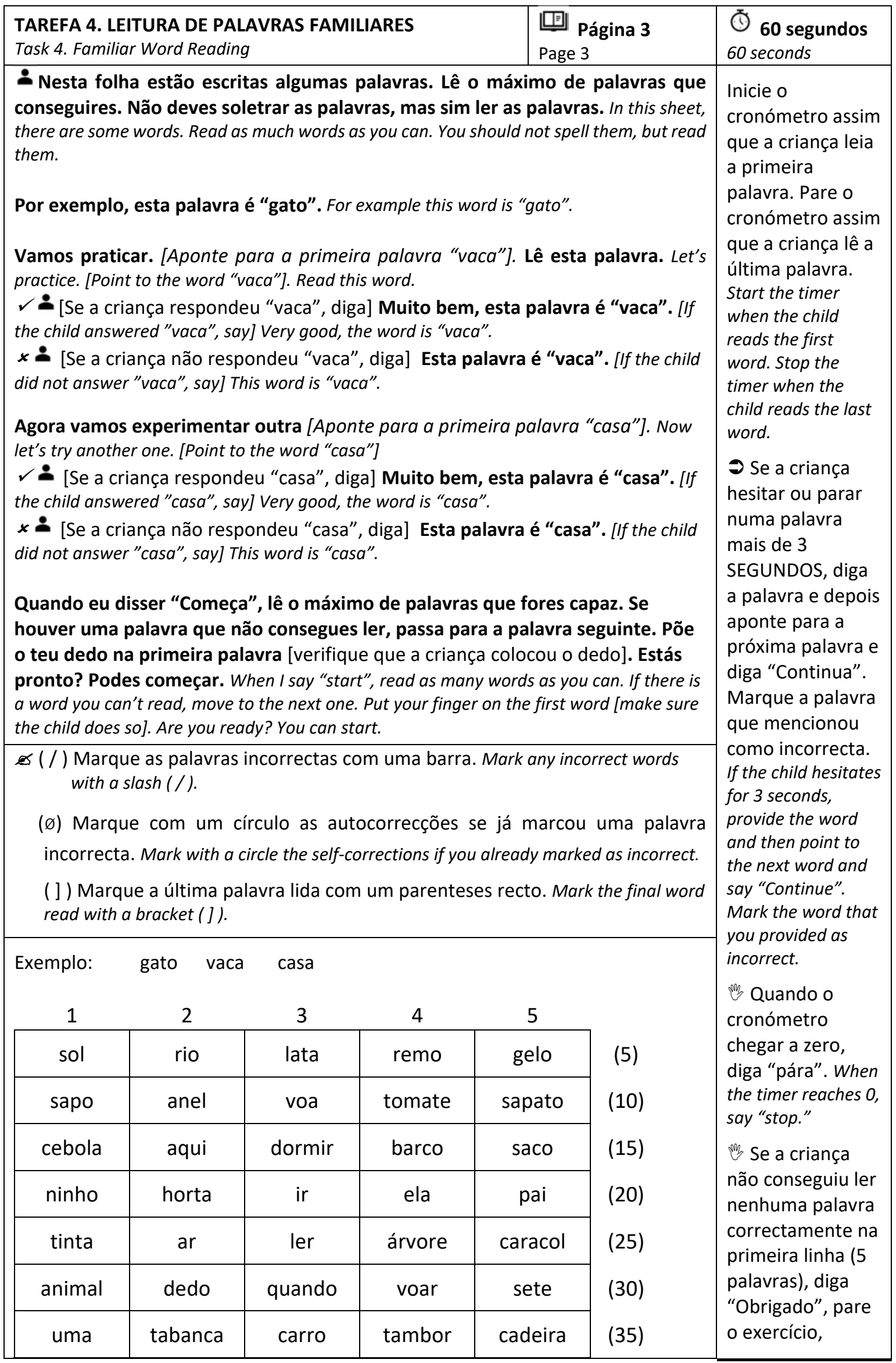


ROPE

Effective Intervention

EGRA Guiné-Bissau, Novembro 2017

\begin{tabular}{|c|c|c|c|c|c|c|}
\hline cantar & canoa & gazela & sempre & dia & \multirow{4}{*}{$\begin{array}{l}(40) \\
(45) \\
(50)\end{array}$} & \multirow{4}{*}{\begin{tabular}{|l} 
marque no \\
quadro abaixo e \\
passe para o \\
próximo \\
exercício. If the \\
child does not \\
provide a single \\
correct response on \\
the first line (5 \\
words), say "Thank \\
you!", discontinue \\
this subtask, check \\
the box at the \\
bottom, and go on \\
to the next subtask. \\
\end{tabular}} \\
\hline mão & gostar & azul & bola & beber & & \\
\hline \multirow[t]{2}{*}{ terra } & arroz & pé & guiar & fonte & & \\
\hline & & & & & & \\
\hline \multicolumn{6}{|c|}{$\begin{array}{l}\text { Tempo restante no cronómetro no momento em que terminou (SEGUNDOS). } \\
\text { Time remaining on stopwatch at completion (SECONDS) }\end{array}$} & \\
\hline \multicolumn{6}{|c|}{$\begin{array}{l}\text { Exercício descontinuado porque a criança não disse nenhuma letra correcta } \\
\text { na primeira linha. Exercise discontinued because the child had no correct answers in the } \\
\text { first line }\end{array}$} & \\
\hline \multicolumn{4}{|l|}{$N A:$} & \multicolumn{2}{|c|}{$N E:$} & \\
\hline
\end{tabular}

Obrigada, vamos passar para o exercício seguinte. Thank you, let's move to the next task. 


\begin{tabular}{|c|c|c|c|c|c|}
\hline \multicolumn{2}{|l|}{ TAREFA 5a. LEITURA Reading } & (7) 60 segundos & \multicolumn{3}{|l|}{ SECÇÃO 5b. COMPREENSÃO DA LEITURA Reading Con } \\
\hline \multicolumn{2}{|l|}{ 미 Página 5. Page 5.} & \multirow{9}{*}{$\begin{array}{l}\text { Inicie o cronómetro assim } \\
\text { que a criança lê a primeira } \\
\text { palavra. Start the timer when } \\
\text { the child reads the first word. } \\
\text { O Se a criança hesitar ou } \\
\text { parar numa palavra mais de } \\
3 \text { SEGUNDOS, aponte para a } \\
\text { próxima palavra e diga } \\
\text { "Continua". If the child } \\
\text { hesitates or stops more than } 3 \\
\text { seconds on a word, move to the } \\
\text { next word and say "Continue". } \\
\text { my Quando o cronómetro } \\
\text { chegar a zero, diga "pára". } \\
\text { When the timer reaches 0, say } \\
\text { "stop." }\end{array}$} & \multirow{2}{*}{\multicolumn{3}{|c|}{$\begin{array}{l}\text { Quando a criança acabar de ler, ou os } 60 \text { segundos terminarem, } \\
\text { RETIRE a história da frente da criança e pergunte a primeira questão. } \\
\text { When the child finishes reading, REMOVE the passage from the child's view } \\
\text { and ask the first question. }\end{array}$}} \\
\hline \multicolumn{2}{|c|}{$\begin{array}{l}\text { Mostre à criança a folha do livro do aluno enquanto lê as } \\
\text { instruções. Show to the children the page of the stimulus } \\
\text { booklet while you read the instructions. }\end{array}$} & & & & \\
\hline \multirow{2}{*}{\multicolumn{2}{|c|}{$\begin{array}{l}\text { ¿ Temos aqui uma pequena história. Lê esta história em } \\
\text { voz alta, sem demora e correctamente. Quando acabares } \\
\text { de ler, vou fazer algumas perguntas sobre a história. } \\
\text { Quando eu disser "Começa", lê a história o melhor que } \\
\text { puderes. Se houver uma palavra que não consegues ler, } \\
\text { passa para a palavra seguinte. Põe o teu dedo na primeira } \\
\text { palavra. Estás pronto? Podes começar. Here is a short } \\
\text { story. I would like that you read this story aloud, quickly but } \\
\text { carefully. When you finish, I will ask you some questions } \\
\text { about the story. When I say "Start", read the story the best } \\
\text { you can. If there is a word that you cannot read, go to the } \\
\text { next one. Ready? You can start. }\end{array}$}} & & \multicolumn{3}{|c|}{$\begin{array}{l}\text { Pergunte à criança somente as perguntas relacionadas com o texto } \\
\text { lido. Uma criança deve ter lido a parte do texto que corresponde a } \\
\text { uma pergunta. Se uma criança não der uma resposta depois de } 10 \\
\text { segundos, marque "não respondeu" e passe para a pergunta seguinte } \\
\text { Não repita as perguntas. Ask the child only the questions related to the } \\
\text { text read. The child should have read the part of the text that correspond to } \\
\text { the question. If a child does not give an answer after } 10 \text { seconds, mark "no } \\
\text { response" and move to the next question. Do not repeat the questions. }\end{array}$} \\
\hline & & & \multicolumn{3}{|c|}{$\begin{array}{l}\text { Agora vou-te fazer algumas perguntas sobre a história que } \\
\text { acabaste de ler. Responde às perguntas o melhor que conseguires. } \\
\text { Podes responder na língua que preferires. Now I am going to ask you } \\
\text { about the story you just read. Answer the questions the best you can. }\end{array}$} \\
\hline \multirow{2}{*}{\multicolumn{2}{|c|}{$\begin{array}{l}\text { (/) Marque as palavras incorrectas com uma barra } \\
\text { (ø) Marque com um círculo as autocorrecções se já } \\
\text { marcou uma palavra incorrecta } \\
\text { (]) Marque a última palavra lida com um parenteses }\end{array}$}} & & \multicolumn{3}{|l|}{$\begin{array}{l}(\checkmark) 1=\text { Correcto } \\
(\checkmark) 0=\text { Incorrecto } \\
(\checkmark) .=\text { Sem resposta }\end{array}$} \\
\hline & & & \multicolumn{3}{|l|}{ Perguntas [Respostas] Questions [Answers] } \\
\hline amiga vaca The monkey & 7 & & & 1 & 0 \\
\hline $\begin{array}{l}\text { para irem à } \\
\text { roubar bana } \\
\text { to go to und }\end{array}$ & 19 & & & 1 & 0 \\
\hline $\begin{array}{l}\text { mas a } \\
\text { fazer is }\end{array}$ & 34 & & ( & 1 & 0 \\
\hline
\end{tabular}
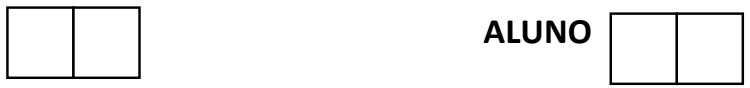


\begin{tabular}{|c|c|c|c|c|c|c|c|c|}
\hline $\begin{array}{l}\text { but the cow was upset and said: - We cannot do that, } \\
\text { to steal is very ugly. }\end{array}$ & & \multirow{3}{*}{$\begin{array}{l}\text { Se a criança disser "Não sei" } \\
\text { marque como incorrecto. If } \\
\text { the child says "I don't know", } \\
\text { mark incorrect. } \\
\text { Fazer a última pergunta } \\
\text { mesmo se a criança } \\
\text { conseguir ler somente até à } \\
\text { palavra } 60 . \text { Ask the last } \\
\text { question even if the child only } \\
\text { reads up to word } 60 \text {. }\end{array}$} & \multicolumn{4}{|c|}{$\begin{array}{l}\text { [Porque roubar é uma coisa muito feia; Porque o } \\
\text { macaco queria roubar](considere todas as respostas } \\
\text { sensatas como correctas) [Because to steal is very bad; } \\
\text { because the monkey wanted to steal (consider all sensible } \\
\text { answers as correct] }\end{array}$} & & \\
\hline $\begin{array}{l}\text { Vamos pedir ao Tio Mussa para nos oferecer uma } \\
\text { banana. } \\
\text { A vaca e o macaco foram à horta e o Tio Mussa } \\
\text { deu-lhes uma banana. } \\
\text { Let's ask uncle Mussa to offer us one banana. } \\
\text { The cow and the monkey went to the garden and uncle } \\
\text { Mussa gave them a banana. }\end{array}$ & 59 & & \multicolumn{3}{|c|}{$\begin{array}{l}\text { O que é o Tio Mussa deu ao macaco e à vaca? What did } \\
\text { uncle Mussa gave to the monkey and the cow? } \\
\text { [Uma banana / bananas / uma banana para cada um] } \\
\text { [One banana /bananas /one banana for each one] }\end{array}$} & 1 & 0 & \\
\hline $\begin{array}{l}\text { O macaco e a vaca ficaram muito felizes. } \\
\text { The monkey and the cow were very happy. }\end{array}$ & 67 & & \multicolumn{3}{|c|}{$\begin{array}{l}\text { Como é que o Tio Mussa se teria sentido se } \\
\text { descobrisse o que é que o macaco queria fazer? How } \\
\text { would uncle Mussa feel if he found out what the monkey } \\
\text { wanted to do? } \\
\text { ([Triste / zangado] [Sad / } \mathrm{mad}]\end{array}$} & 1 & 0 & \\
\hline \multicolumn{2}{|l|}{$\begin{array}{l}\text { Tem Tempo restante no cronómetro no momento em que } \\
\text { terminou (SEGUNDOS) Time remaining on stopwatch at } \\
\text { completion (SECONDS) }\end{array}$} & & \multicolumn{3}{|c|}{$\begin{array}{l}\text { Exercício descontinuado porque a criança não deu } \\
\text { leu nenhuma palavra correctamente antes da palavra } \\
\text { dentro da caixa Exercise discontinued because the child did } \\
\text { not read any word correct before the boxed word. }\end{array}$} & & & \\
\hline$N A(5 a):$ & $N E(5 a):$ & & $N A(5 b):$ & & $N E(5 b):$ & & & \\
\hline \multicolumn{9}{|c|}{$\begin{array}{l}\text { Que língua(s) é que a criança usou nesta tarefa? (circule todas as linguas que foram faladas) } \\
\text { Which languages did the child use in this task? (circle all answers that apply) }\end{array}$} \\
\hline \multicolumn{2}{|l|}{ Português } & \multicolumn{2}{|c|}{ Mandinga } & \multicolumn{2}{|l|}{ Beafada } & & & \\
\hline
\end{tabular}

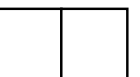


ROPE | EGRA Guiné-Bissau, 2017

Obrigada, vamos passar para o exercício seguinte. Thank you, let's move to the next task.

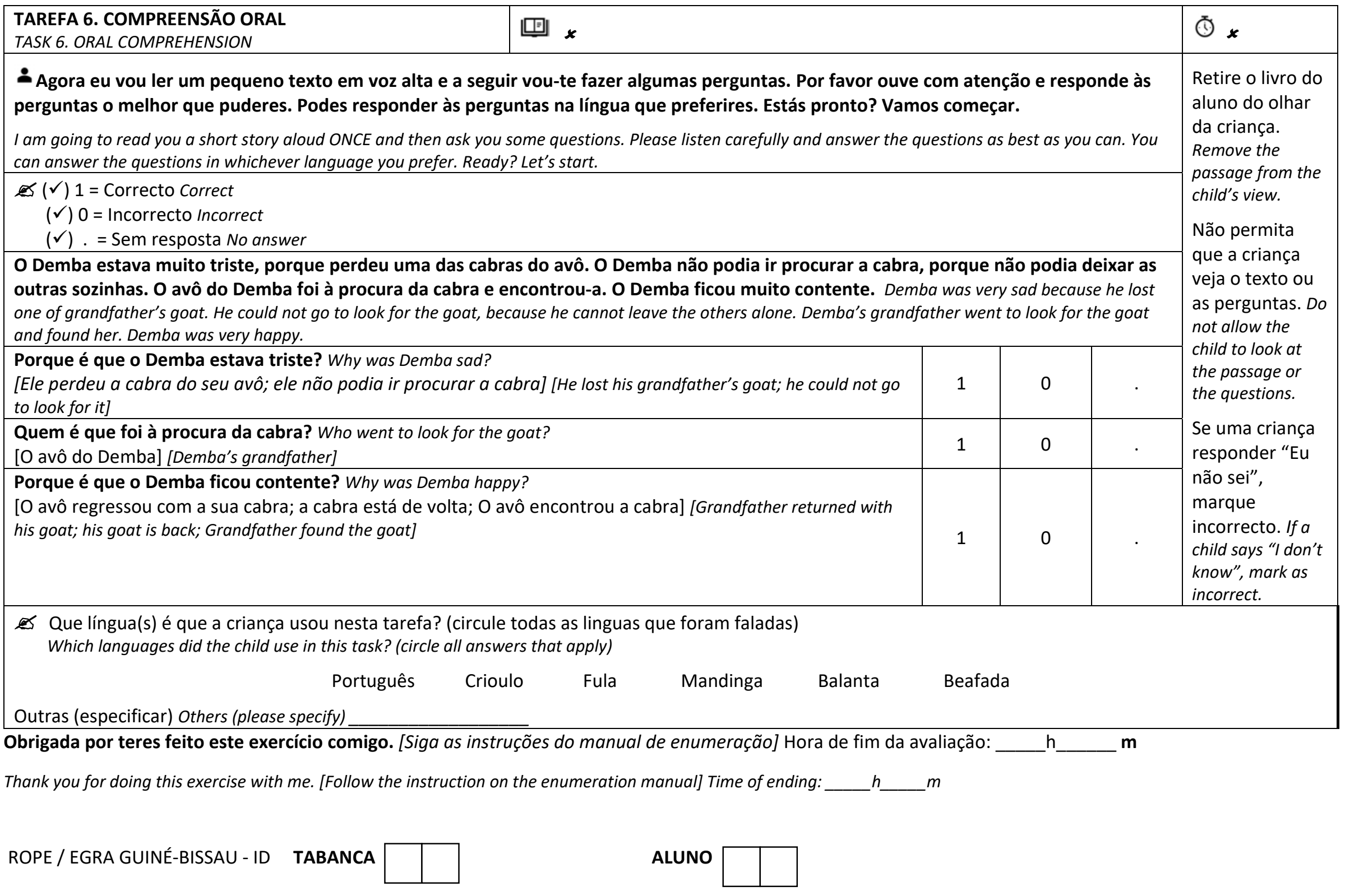


ROPE

Effective Intervention EGRA Guiné-Bissau, Novembro 2017

Que língua(s) é que usou para administrar este teste? (circule todas as opções que se apliquem) Which language(s) did you use to apply this test? (circle all answers that apply)
Português
Crioulo
Fula
Balanta
Beafada
Outras 
Teste de Matemática em língua Portuguesa na Guiné-Bissau: Formulário de Instruções para o Administrador e Respostas dos alunos

Portuguese Early Grade Mathematics Assessment in Guinea Bissau: Instructions for Enumerators and Children Response Form

\section{MATEMÁTICA Mathematics}

\section{$\underline{\text { Instruções Gerais }}$}

É importante estabelecer uma relação descontraída e de confiança com a criança que vai ser avaliada através de uma conversa inicial com questões de interesse para a criança (ver exemplo abaixo). A criança deve ver este exercício mais como um jogo do que uma avaliação. É importante que leia SOMENTE em voz alta o texto que está a negrito, de forma calma e clara, para que a criança possa compreender os exercícios. It is important to establish a playful and relaxed relationship with the child that will be assessed through an initial talk on topics of interest to the child (see example below). The child should perceive the assessment more as a game rather than an evaluation. It is important that you ONLY read aloud the text in bold, slowly and clearly, so that the child can understand the exercises.

\section{Bom dia, o meu nome é} . E tu, como te chamas? Eu gosto muito de E tu, o que mais gostas de fazer? Agora que já fizeste uns jogos de leitura com o meu colega, vamos fazer uns jogos de matemática. Ao longo deste exercício podes responder na língua que preferires. Pode ser? Estás pronto? Vamos começar! Good morning. My name is And you, what's your name? I like to . And you, what do you like to do? Now that you have done some reading games with my colleague, let's do some maths game. Throughout this exercise, you can answer in the language that you prefer. Is that ok? Are you ready? Let's start.

\begin{tabular}{|l|l|l|l|}
\hline A. Data: Date: & Nof & $\begin{array}{l}\text { D. Nome da Criança: } \\
\text { Name of child: }\end{array}$ & \\
\hline $\begin{array}{l}\text { B. Hora Início: } \\
\text { assessment start time: }\end{array}$ & & $\begin{array}{l}\text { E. Código da Criança } \\
\text { Code of child: }\end{array}$ & \\
\hline $\begin{array}{l}\text { C. Code of } \\
\begin{array}{l}\text { Enumerador: Code of } \\
\text { Enumerator: }\end{array}\end{array}$ & & & \\
\hline
\end{tabular}
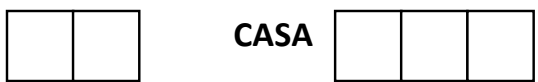


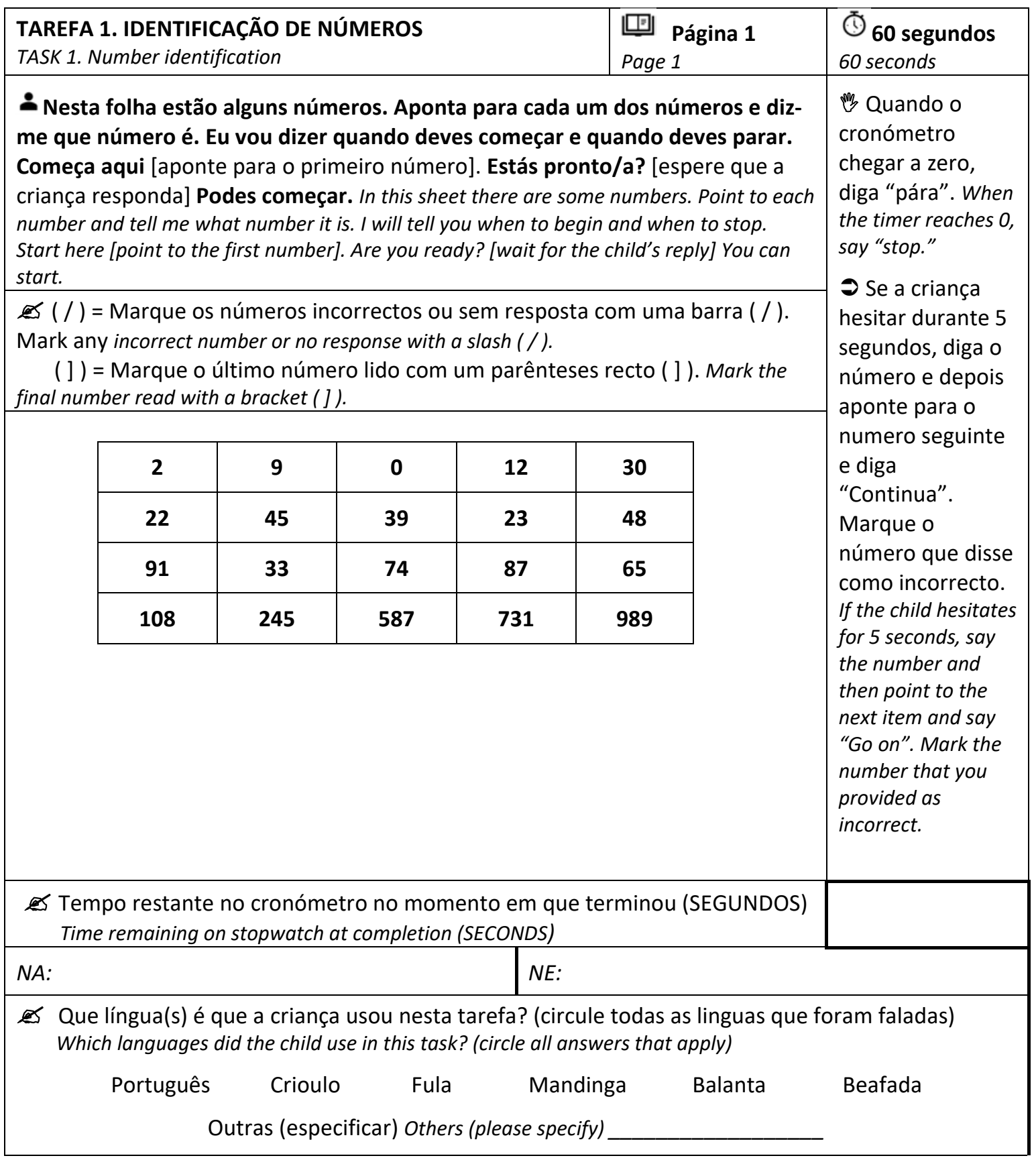

Obrigada, vamos passar para o exercício seguinte. Thank you, let's move to the next task.

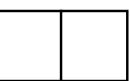


TAREFA 2. DISCRIMINAÇÃO DE NÚMEROS (exemplos)

TASK 2. Number discrimination (examples)

\begin{tabular}{|l|l|}
$\begin{array}{l}\text { 미 Página } 2 \\
\text { Page 2 }\end{array}$ & (5) \\
\hline
\end{tabular}

P1

Olha para estes números. Diz-me qual deles é maior. [Só se pode considerar a resposta correcta se as crianças "disserem" o número maior, apontar não é suficiente] Look at these numbers. Tell me which number is bigger [students can only be considered correct if they "say" the bigger number, pointing is not enough].

\section{4}

$\checkmark$ [Se a criança respondeu 8, diga] Muito bem, 8 é o maior. Vamos fazer outro exemplo. [If the child answered 8, say] Well done, 8 is bigger. Let's do another example.

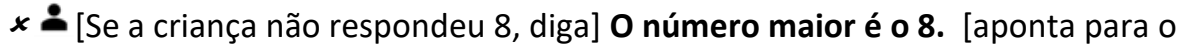
8] Este é 8. [aponta para o 4] Este é o 4. 8 é maior do que 4. Vamos fazer outro exemplo. [If the child did not answer 8, say] The bigger number is 8. [Point to 8] This is 8 . [Point to 4] This is 4.8 is bigger than 4. Let's do another example.

P2

¿ Olha para estes números. Diz-me qual deles é maior. Look at these numbers. Tell me which number is bigger.

1012

[Se a criança respondeu 12, diga] Muito bem, 12 é o maior. Vamos continuar. [If the child answered 12, say] Well done, 12 is bigger. Let's continue.

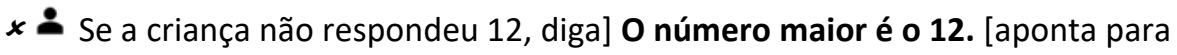
o 10] Este é 10. [aponta para o 12] Este é o 12.12 é maior do que 10. Vamos continuar. [If the child did not answer 12, say] The bigger number is 12. [Point to 10] This is 10. [Point to 12] This is 12.12 is bigger than 10. Let's continue.

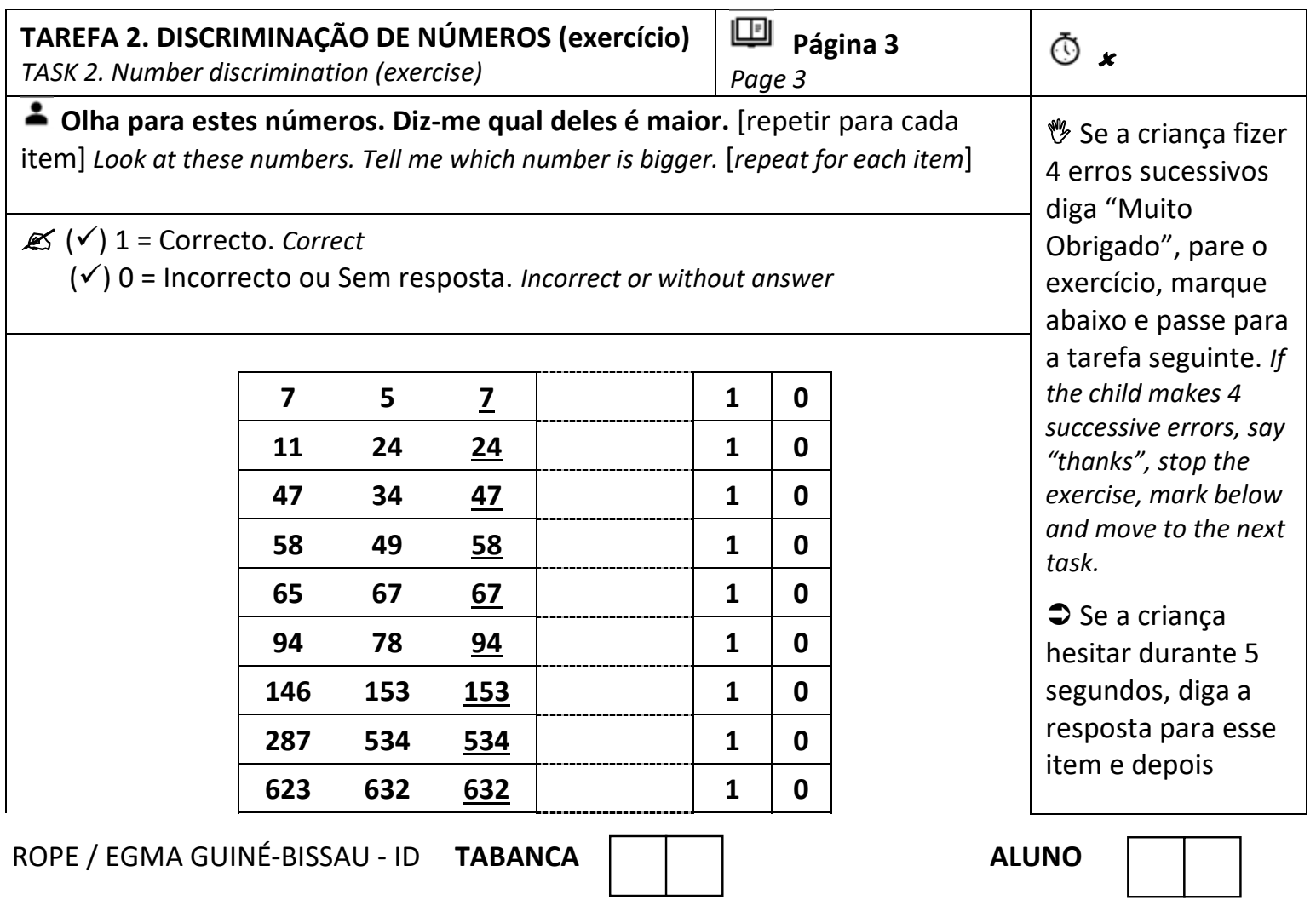




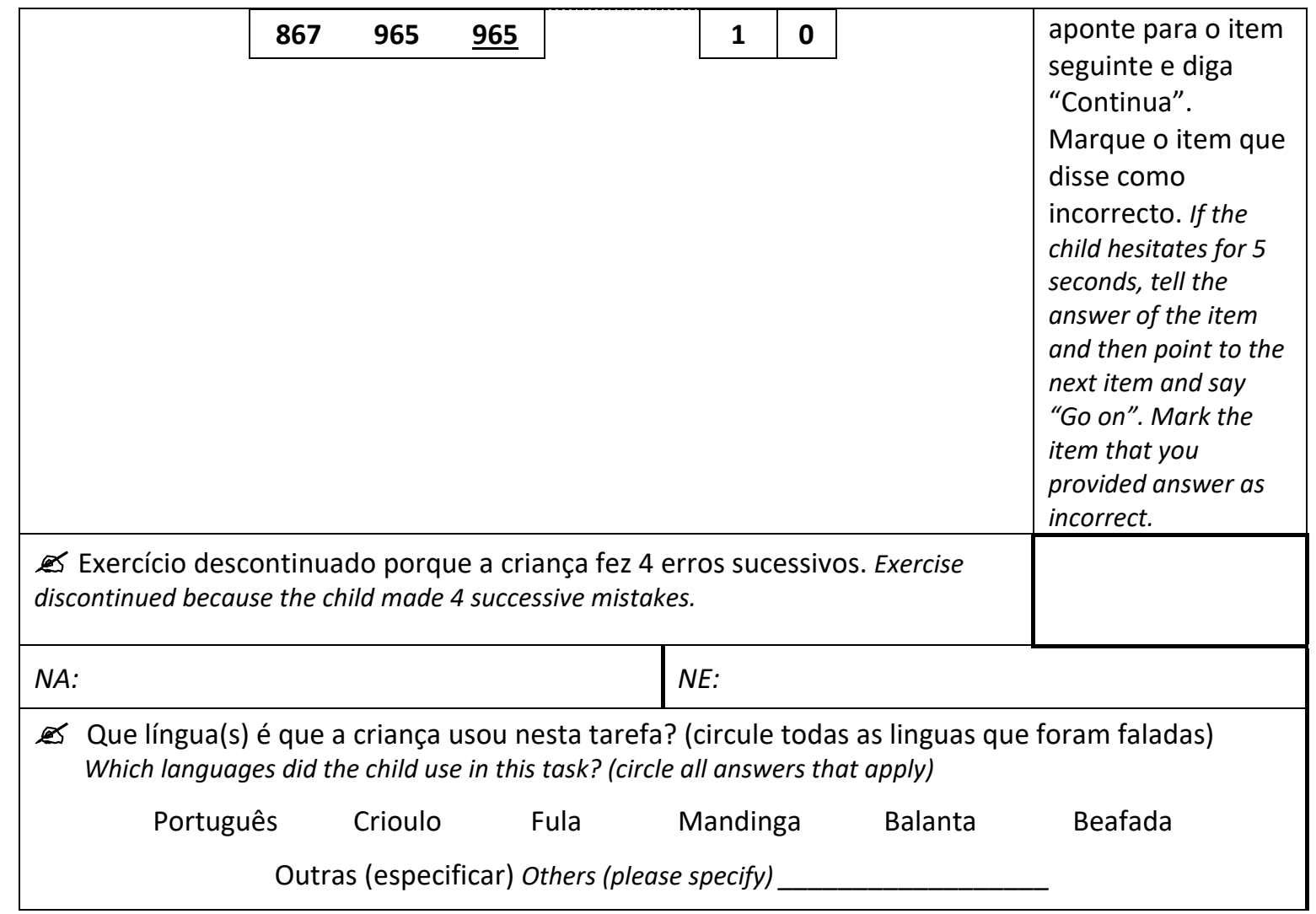

Obrigada, vamos passar para o exercício seguinte. Thank you, let's move to the next task.

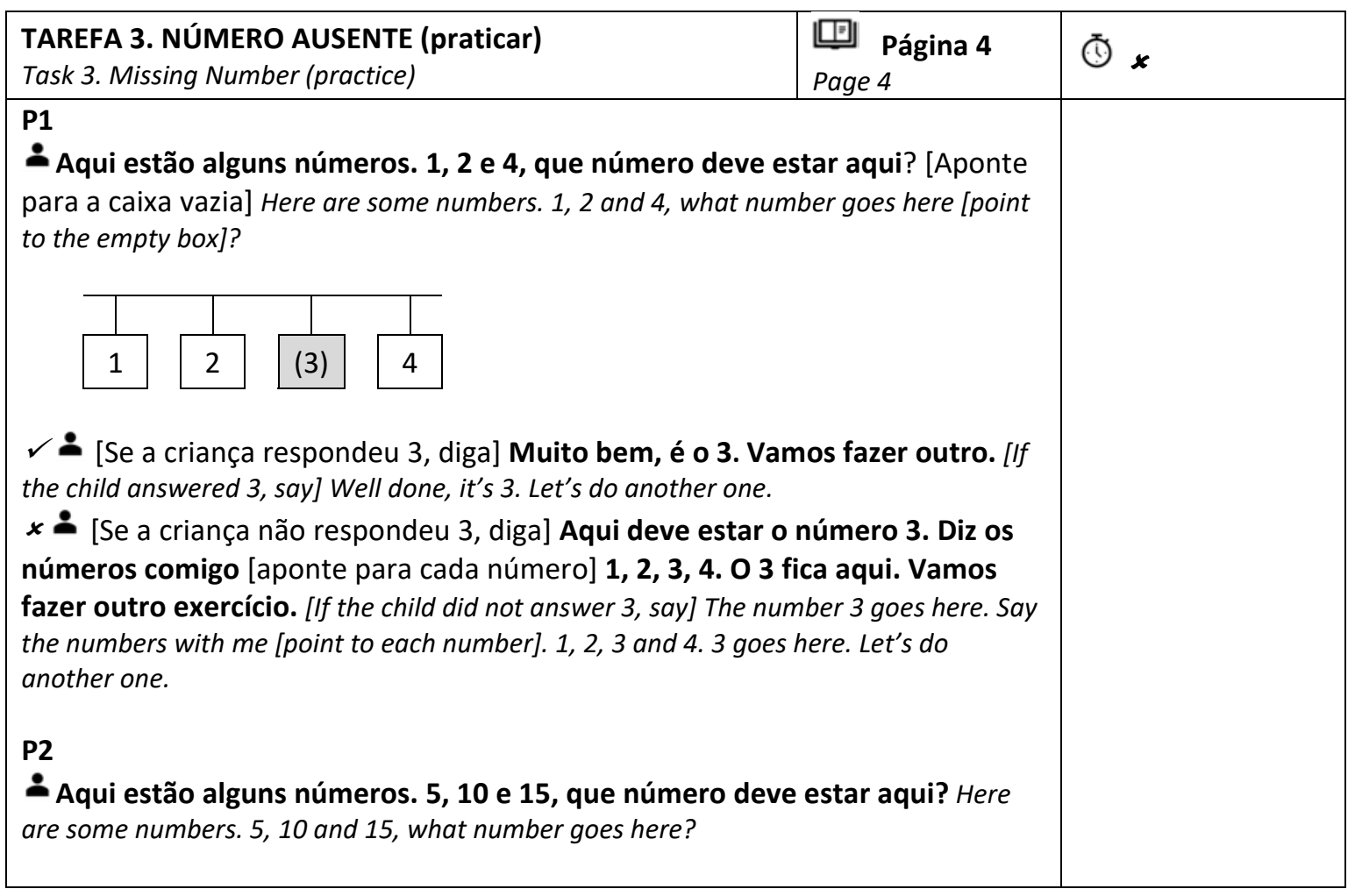

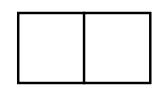




\begin{tabular}{|l|l|l|}
\hline 5 & \\
\hline
\end{tabular}

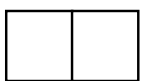




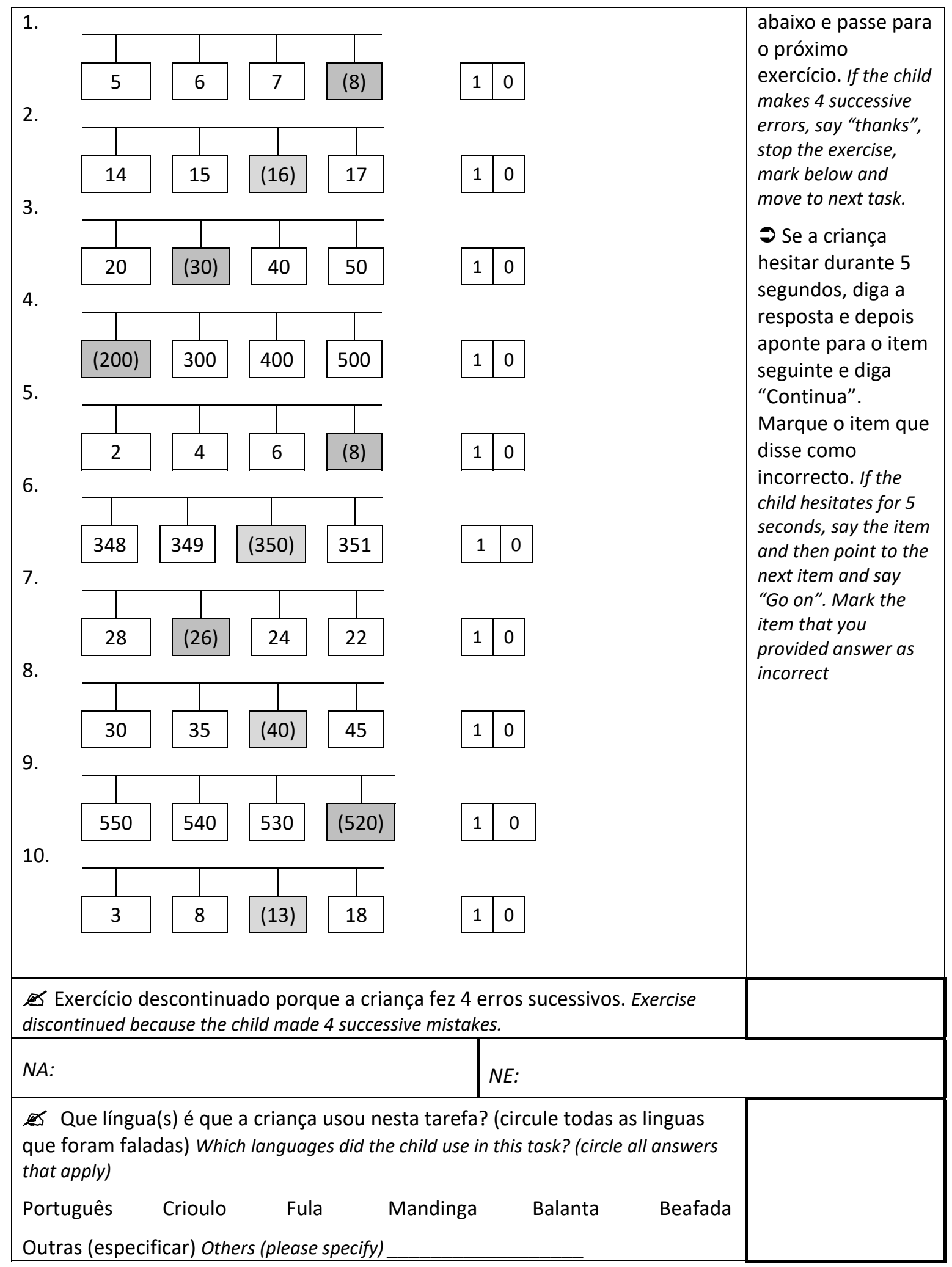

Obrigada, vamos passar para o exercício seguinte. Thank you, let's move to the next task.

TAREFA 4A. ADIÇÃo (Nível 1)

Task 4A. Addition (level 1)
멸 Página 7 e 8 Page 7 and 8
(1) 60 segundos 60 seconds

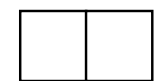


Papel e lápis. Paper and pencil

- Nestas duas páginas estão algumas somas [aponte com o dedo de cima para baixo, mostrando as duas páginas]. Podes usar este papel e este lápis se quiseres, mas não é obrigatório. Eu vou te dizer quando deves começar e quando deves parar. Diz-me as respostas para cada soma. Se não souberes uma resposta, avança para a soma seguinte. Estás pronto? ([espere que a criança responda] Começa aqui [aponte para a primeira soma]. In these two pages there are some addition problems [glide hand from top to bottom on the two pages].You can use this paper and pencil if you want to, but it is not mandatory. I will tell when to start and when to stop. Say the answer for each problem. If you don't know an answer, move to the next problem. Are you ready (wait until the child responds)? Start here [point to the first problem].

$(\checkmark) 1=$ Correcto. Correct

$(\checkmark) 0=$ Incorrecto ou Sem resposta. Incorrect or without answer

( ] ) = Até aonde a criança chegou aos 60 segundos. At the point reached by the child after 60 seconds.

\begin{tabular}{|l|}
\hline $1+3=(4)$ \\
\hline $3+2=(5)$ \\
\hline $6+2=(8)$ \\
\hline $4+5=(9)$ \\
\hline $3+3=(6)$ \\
\hline $8+1=(9)$ \\
\hline $7+3=(10)$ \\
\hline $3+9=(12)$ \\
\hline $2+8=(10)$ \\
\hline $9+3=(12)$ \\
\hline
\end{tabular}

\begin{tabular}{|l|l|}
\hline 1 & 0 \\
\hline 1 & 0 \\
\hline 1 & 0 \\
\hline 1 & 0 \\
\hline 1 & 0 \\
\hline 1 & 0 \\
\hline 1 & 0 \\
\hline 1 & 0 \\
\hline 1 & 0 \\
\hline 1 & 0 \\
\hline
\end{tabular}

A criança usou: The child used:

\begin{tabular}{|l|l|}
\hline & Os dedos para contar. Fingers to count. \\
\hline & Papel e lápis. Paper and pencil. \\
\hline & Resolveu a questão de cabeça. Solved the question in his/her head. \\
\hline
\end{tabular}

Marque com $\checkmark$ todas as respostas que se apliquem. Tick all answers that apply.
Quando o cronómetro chegar a zero, diga "pára". When the timer reaches 0 , say "stop."

Se a criança fizer 4 erros sucessivos diga "Muito Obrigado", pare o exercício, marque no quadro abaixo e passe para 0 próximo exercício. If the child makes 4 successive errors, say "thanks", stop the exercise, mark below and move to next task.

- Se a criança hesitar durante 5 segundos, diga a resposta e depois aponte para o item seguinte e diga "Continua". Marque o item que disse como incorrecto. If the child hesitates for 5 seconds, provide the answer and then point to the next item and say "Go on". Mark the item that you provided answer as incorrect.

Tempo restante no cronómetro no momento em que terminou (SEGUNDOS). Time remaining on stopwatch at completion (SECONDS)

Exercício descontinuado porque a criança fez 4 erros sucessivos. Exercise discontinued because the child made 4 successive mistakes.

NA: NE:

Que língua(s) é que a criança usou nesta tarefa? (circule todas as linguas que foram faladas) Which languages did the child use in this task? (circle all answers that apply)

Português Crioulo Fula Mandinga Balanta Beafada

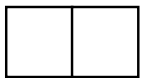


Outras (especificar) Others (please specify)

Obrigada, vamos passar para o exercício seguinte. Thank you, let's move to the next task.

\begin{tabular}{|c|c|c|c|}
\hline \multicolumn{2}{|l|}{$\begin{array}{l}\text { TAREFA 4B. ADIÇÃO (Nível 2) } \\
\text { Task 4B. Addition (level 2) }\end{array}$} & $\begin{array}{l}\text { Página } 9 \\
\text { Page } 9\end{array}$ & \multirow{3}{*}{\begin{tabular}{|l}
\multicolumn{1}{c}{$\boldsymbol{x}$} \\
Não fazer esta \\
tarefa se a criança \\
não tiver \\
respondido \\
correctamente a \\
nenhum exercício \\
de adição nível 1. \\
Skip this subtask if \\
the child scores zero \\
in level 1 Addition \\
questions.
\end{tabular}} \\
\hline \multicolumn{3}{|l|}{$\checkmark /$ Papel e lápis. Paper and pencil } & \\
\hline \multicolumn{3}{|c|}{$\begin{array}{l}\text { Aqui estão algumas somas [aponte com o dedo de cima para baixo]. Podes } \\
\text { usar este papel e este lápis se quiseres, mas não é obrigatório. Eu vou } \\
\text { te dizer quando deves começar e quando deves parar. Diz-me as } \\
\text { respostas para cada soma. Se não souberes uma resposta, avança para } \\
\text { a soma seguinte. Estás pronto? [espere que a criança responda] Começa } \\
\text { aqui [aponte para a primeira soma]. Here are some addition questions [glide hand } \\
\text { from top to bottom]. You may use this paper and pencil if you want to, but it is not } \\
\text { mandatory. Tell me the answers for each question. if you do not know the answer, move } \\
\text { to the next one. Are you ready? [wait until the child responds] Start here (point to the } \\
\text { first problem] }\end{array}$} & \\
\hline \multicolumn{3}{|c|}{$\begin{array}{l}(\checkmark) 1=\text { Correcto Correct } \\
(\checkmark) 0=\text { Incorrecto ou Sem resposta Incorrect of without answer }\end{array}$} & $\begin{array}{l}\text { Se a criança } \\
\text { fizer } 4 \text { erros }\end{array}$ \\
\hline $13+6=(19)$ & 1 & 0 & "Muito Obrigado", \\
\hline $18+7=(25)$ & 1 & 0 & marque no quadro \\
\hline $14+25=(39)$ & 1 & 0 & abaixo e passe para \\
\hline $22+37=(59)$ & 1 & 0 & $\begin{array}{l}\text { O proximo } \\
\text { exercício. If the child }\end{array}$ \\
\hline $38+26=(64)$ & & 0 & \\
\hline \multicolumn{3}{|l|}{ A criança usou: The child used: } & mark below and \\
\hline \multicolumn{3}{|l|}{ Os dedos para contar Fingers to count. } & move to next task. \\
\hline \multicolumn{3}{|l|}{ Papel e lápis Paper and pencil. } & Se a criança \\
\hline \multicolumn{3}{|c|}{ Resolveu as somas de cabeça Solved the question in his/her head. } & hesitar durante 5 \\
\hline \multicolumn{3}{|c|}{ Marque com $\checkmark$ todas as respostas que se apliquem. Tick all answers that apply. } & $\begin{array}{l}\text { resposta e depois } \\
\text { aponte para o item } \\
\text { seguinte e diga } \\
\text { "Continua". } \\
\text { Marque o item que } \\
\text { disse como } \\
\text { incorrecto. If the } \\
\text { child hesitates for } 5 \\
\text { seconds, provide the } \\
\text { answer and then } \\
\text { point to the next item } \\
\text { and say "Go on". } \\
\text { Mark the item that }\end{array}$ \\
\hline
\end{tabular}

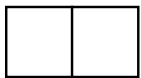




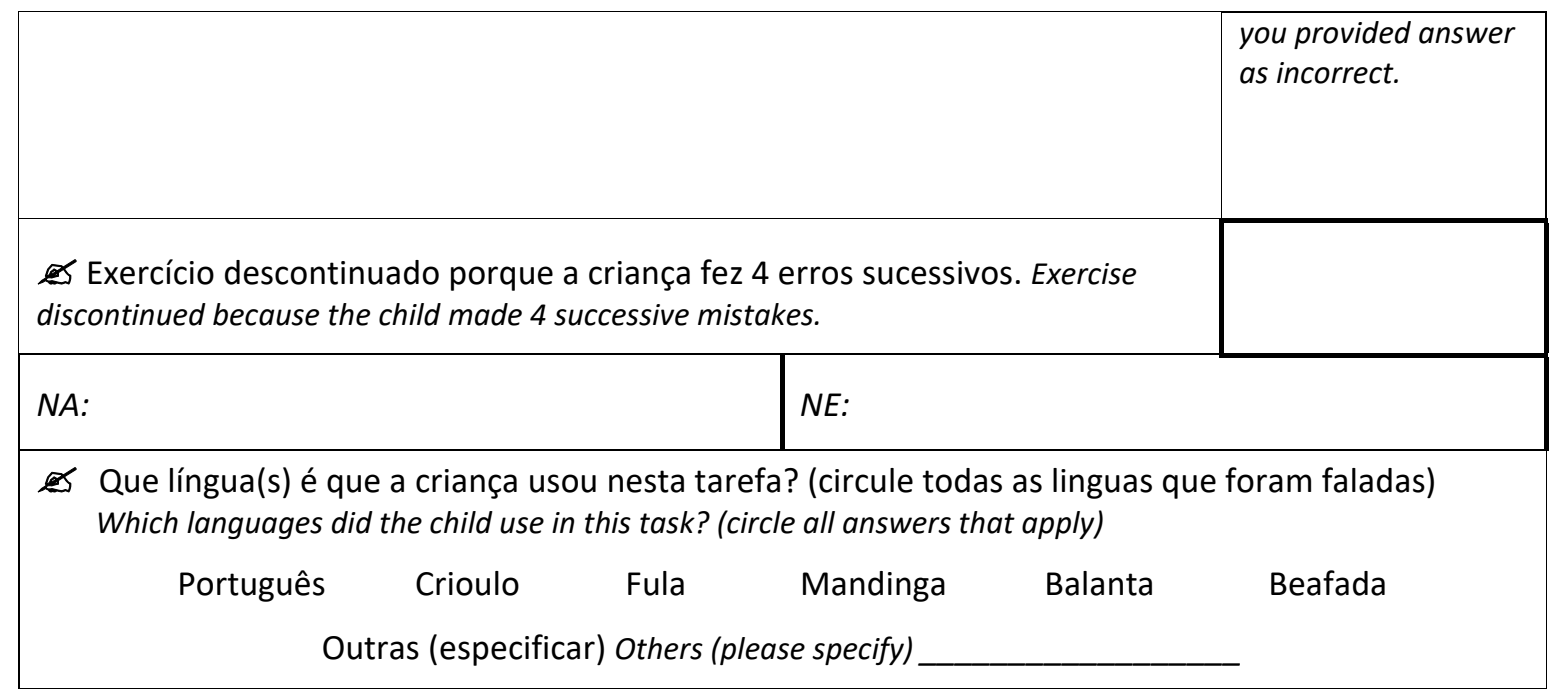

Obrigada, vamos passar para o exercício seguinte. Thank you, let's move to the next task.

\begin{tabular}{|c|c|c|}
\hline $\begin{array}{l}\text { TAREFA 5A. SUBTRACÇÃO (Nível 1) } \\
\text { Task 5A. Subtraction (level 1) }\end{array}$ & $\begin{array}{l}\text { Página } 10 \text { e } 11 \\
\text { Page } 10 \text { and } 11\end{array}$ & $\begin{array}{l}60 \text { segundos } \\
60 \text { seconds }\end{array}$ \\
\hline \multicolumn{2}{|l|}{ Papel e lápis. Paper and pencil } & m Qu \\
\hline \multicolumn{2}{|c|}{$\begin{array}{l}\text { Nestas duas páginas estão algumas subtracções [aponte com o dedo de } \\
\text { cima para baixo, mostrando as duas páginas]. Podes usar este papel e este } \\
\text { lápis se quiseres, mas não é obrigatório. Eu vou-te dizer quando deves } \\
\text { começar e quando deves parar. Diz-me as respostas para cada subtracção. Se } \\
\text { não souberes uma resposta, avança para a subtracção seguinte. Estás } \\
\text { pronto/a? [espere que a criança responda] Começa aqui [aponte para a } \\
\text { primeira soma]. In these two pages there are some subtraction questions [glide hand } \\
\text { from top to bottom, showing the two pages]. You may use this paper and pencil if you } \\
\text { want to, but it is not mandatory. I will tell when to start and when to stop. Say the } \\
\text { answer for each question. If you don't know an answer, move to the next question. Are } \\
\text { you ready? [wait until the child responds] Start here [point to the first problem] }\end{array}$} & $\begin{array}{l}\text { Me a criança fizer } \\
4 \text { erros sucessivos } \\
\text { diga "Muito } \\
\text { Obrigado", pare o } \\
\text { exercício, marque }\end{array}$ \\
\hline $\begin{array}{l}(\checkmark) 1=\text { Correcto } \\
(\checkmark) 0=\text { Incorrecto ou Sem resposta } \\
\text { (]) }=\text { At the point reached by the child at } 60 \text { seconds. }\end{array}$ & & $\begin{array}{l}\text { no quadro abaixo e } \\
\text { passe para o } \\
\text { próximo exercício. }\end{array}$ \\
\hline
\end{tabular}

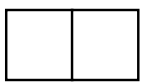


ROPE

\begin{tabular}{|c|c|c|}
\hline $4-1=(3)$ & 1 & 0 \\
\hline $5-2=(3)$ & 1 & 0 \\
\hline $8-2=(6)$ & 1 & 0 \\
\hline $9-5=(4)$ & 1 & 0 \\
\hline $6-3=(3)$ & 1 & 0 \\
\hline $9-8=(1)$ & 1 & 0 \\
\hline $10-7=(3)$ & 1 & 0 \\
\hline $12-3=(9)$ & 1 & 0 \\
\hline $10-2=(8)$ & 1 & 0 \\
\hline $12-9=(3)$ & 1 & 0 \\
\hline
\end{tabular}

\begin{tabular}{|c|c|c|}
\hline $15-7=(8)$ & 1 & 0 \\
\hline $11-4=(7)$ & 1 & 0 \\
\hline $12-7=(5)$ & 1 & 0 \\
\hline $14-8=(6)$ & 1 & 0 \\
\hline $17-9=(8)$ & 1 & 0 \\
\hline $13-6=(7)$ & 1 & 0 \\
\hline $16-8=(8)$ & 1 & 0 \\
\hline $13-8=(5)$ & 1 & 0 \\
\hline $12-10=(2)$ & 1 & 0 \\
\hline $18-8=(10)$ & 1 & 0 \\
\hline
\end{tabular}

If the child makes 4 successive errors, say "thanks", stop the exercise, mark below and move to next task.

$\rightarrow$ Se a criança hesitar durante 5 segundos, diga a resposta e depois aponte para o item seguinte e diga "Continua". Marque o item que disse como incorrecto. If the child hesitates for 5 seconds, provide the answer and then point to the next item and say "Go on". Mark the item that you provided answer as incorrect

Tempo restante no cronómetro no momento em que terminou (SEGUNDOS). Time remaining on stopwatch at completion (SECONDS)

Exercício descontinuado porque a criança fez 4 erros sucessivos. Exercise discontinued because the child made 4 successive mistakes.

NA: NE:

Que língua(s) é que a criança usou nesta tarefa? (circule todas as linguas que foram faladas) Which languages did the child use in this task? (circle all answers that apply)

$$
\text { Português Crioulo Fula Mandinga Balanta Beafada }
$$

Outras (especificar) Others (please specify)

Obrigada, vamos passar para o exercício seguinte. Thank you, let's move to the next task.

\begin{tabular}{|c|c|c|}
\hline $\begin{array}{l}\text { TAREFA 5B. SUBTRACÇÃO (Nível 2) } \\
\text { Task 5B. Subtraction (level 2) }\end{array}$ & $\begin{array}{l}\text { 며 Página } 12 \\
\text { Page } 12\end{array}$ & 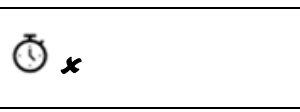 \\
\hline \multicolumn{2}{|l|}{$\square /$ Papel e lápis. Paper and pencil } & \multirow[b]{2}{*}{$\begin{array}{l}\text { Não fazer esta } \\
\text { tarefa se a criança } \\
\text { não tiver } \\
\text { respondido } \\
\text { correctamente a } \\
\text { nenhum exercício } \\
\text { de subtracção nível } \\
\text { 1. Skip this subtask }\end{array}$} \\
\hline \multicolumn{2}{|c|}{$\begin{array}{l}\text { Aqui estão algumas subtracções [aponte com o dedo de cima para baixo]. } \\
\text { Eu vou-te dizer quando deves começar e quando deves parar. Se quiseres } \\
\text { podes usar este papel e lápis, mas não é obrigatório. Diz-me as respostas para } \\
\text { cada subtracção. Se não souberes uma resposta, avança para a subtracção } \\
\text { seguinte. Estás pronto? Começa aqui [aponte para a primeira soma]. Here are } \\
\text { some subtraction problems [glide hand from top to bottom]. I will tell when to start and } \\
\text { when to stop. You may use this paper and pencil if you want to. You do not have to do }\end{array}$} & \\
\hline
\end{tabular}

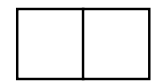




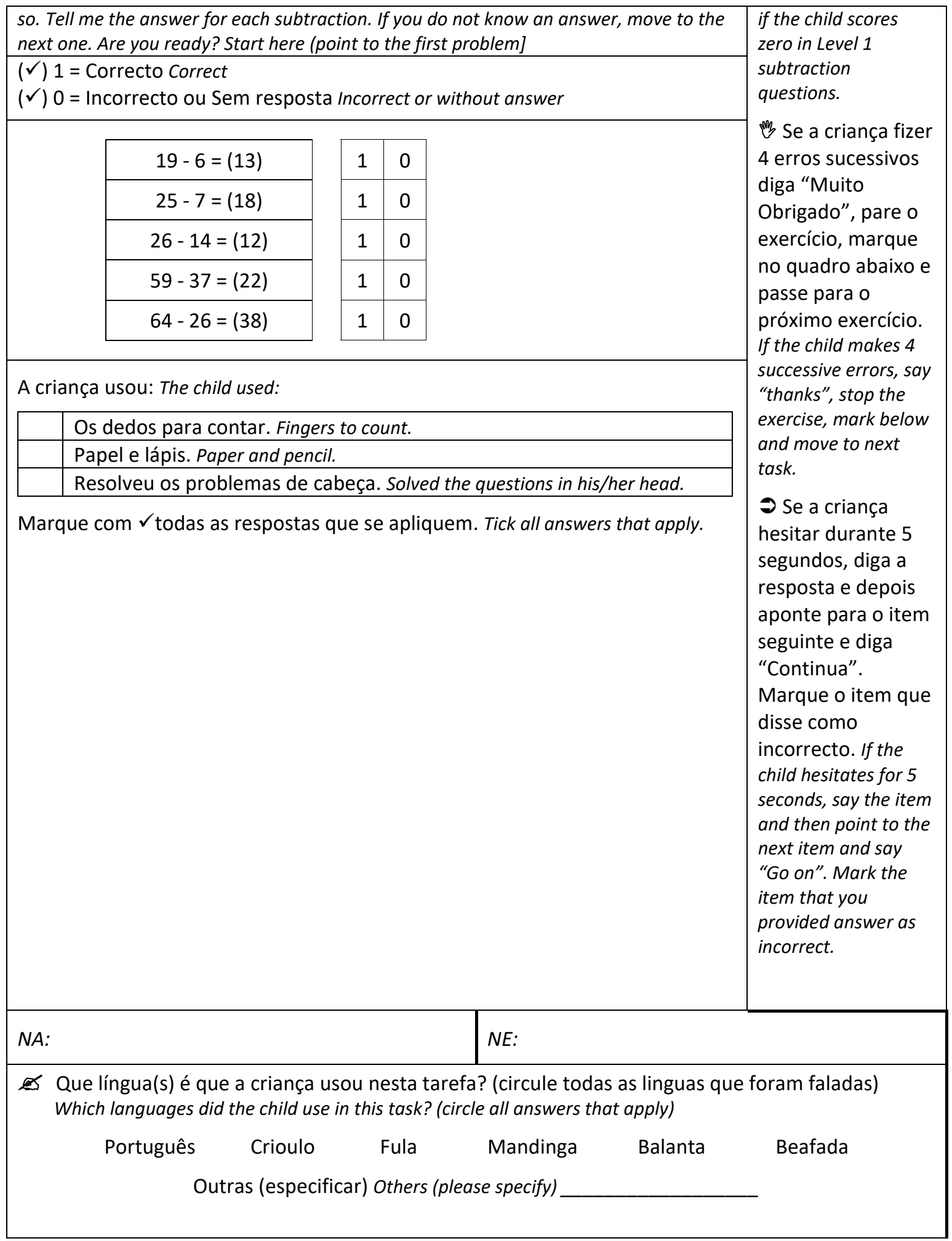

Obrigada, vamos passar para o exercício seguinte. Thank you, let's move to the next task.

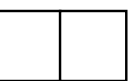




\begin{tabular}{|l|l|}
\hline TAREFA 6. PROBLEMA DE PALAVRAS (praticar) & \multirow{2}{*}{ Task 6. Word problems (practice) } \\
\hline Vou-te ler alguns problemas e vou-te pedir para os resolveres. Aqui estão & Contadores, papel e lápis. Counters, paper and pencil, \\
algumas coisas que podem te ajudar. Podes usá-los se precisares, mas não é \\
obrigatório usá-los. Ouve com muita atenção cada problema. Se precisares \\
eu posso repetir. Estás pronto/a? Vamos começar. I am going to read some \\
problems for you to solve them. If you want you can use these counters, paper and \\
pencil, but it is not mandatory. Listen carefully to each problem. If you need, I can \\
repeat. Ready? Let's start.
\end{tabular}

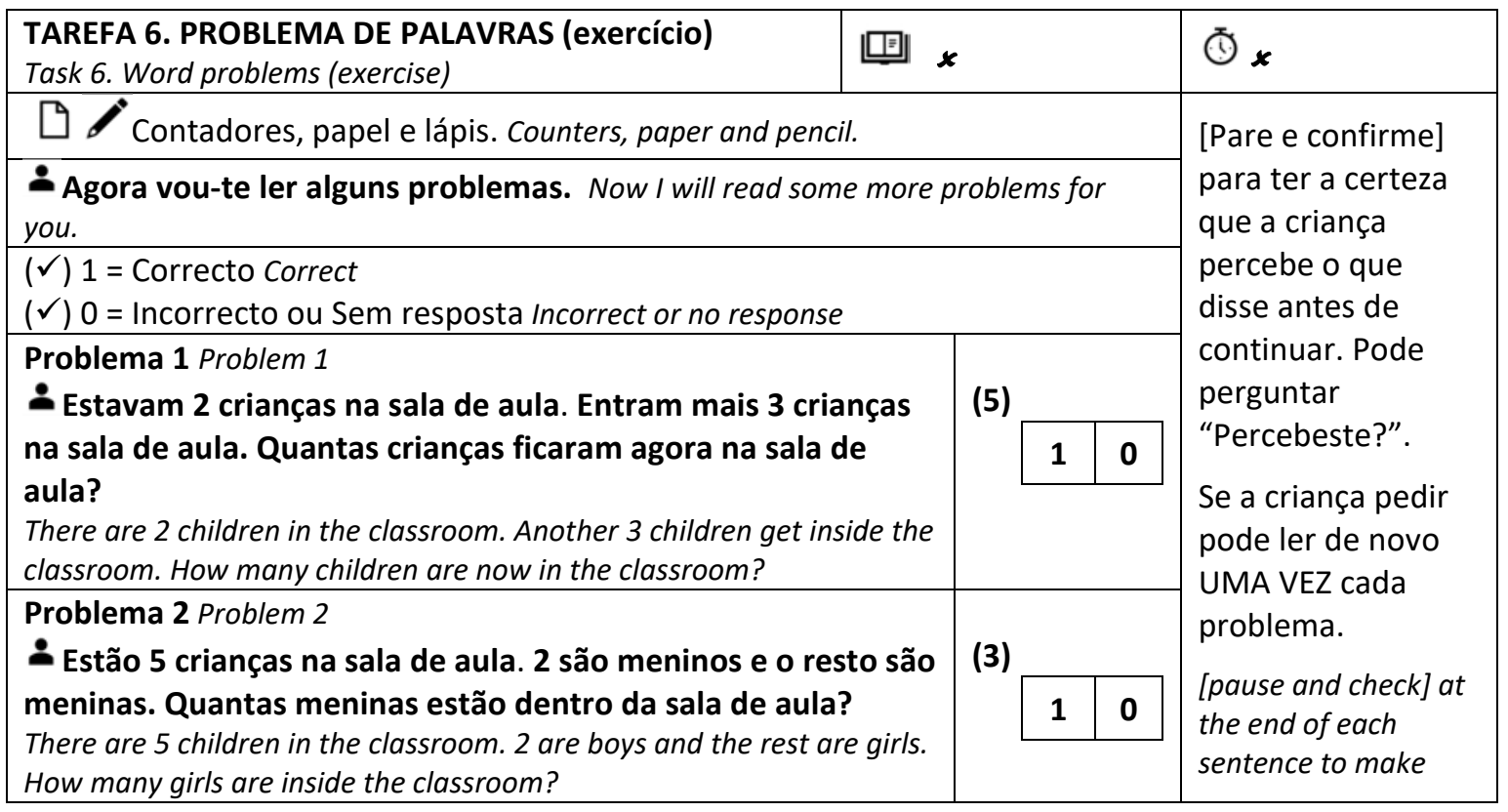

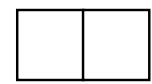




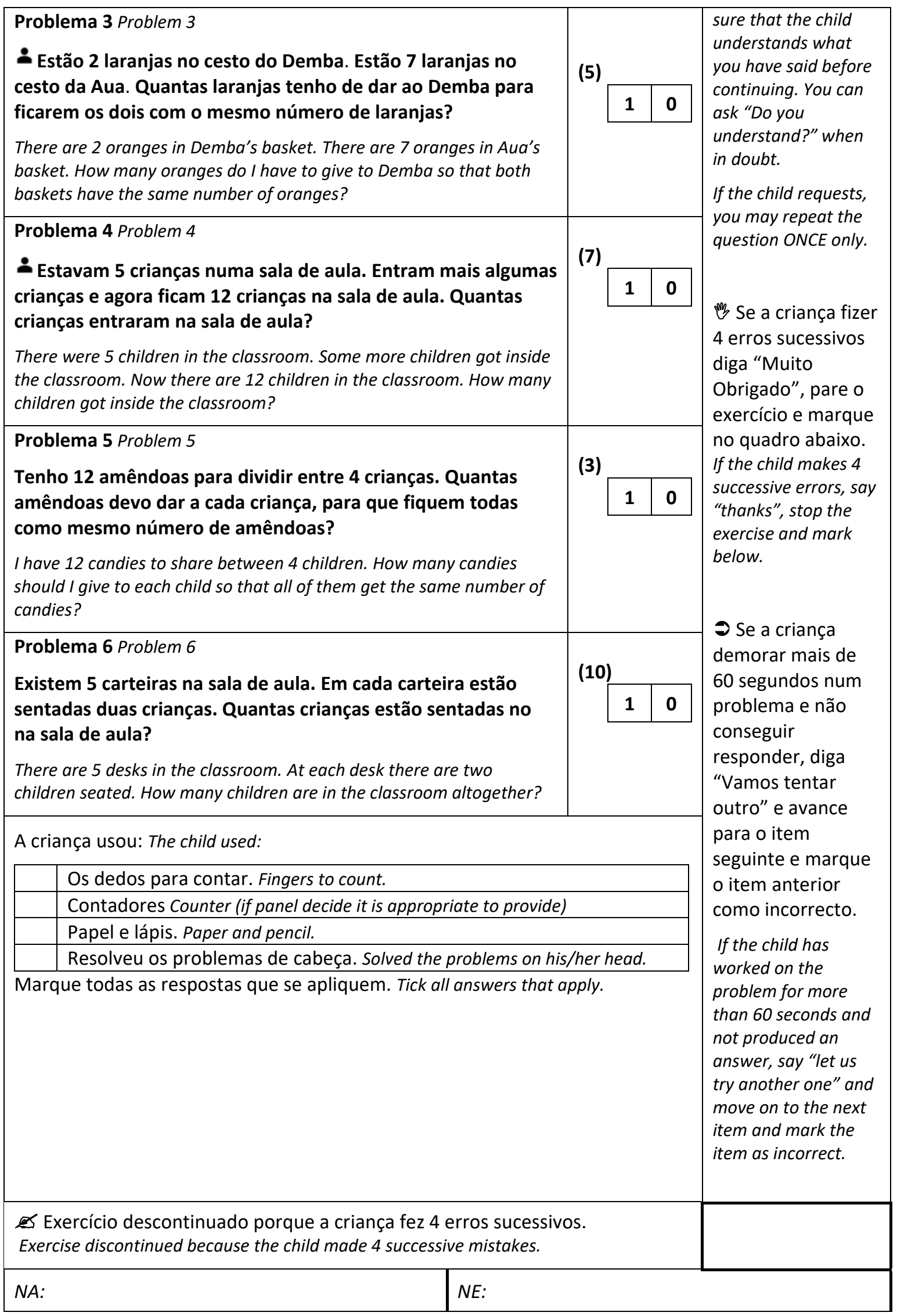

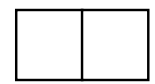


Que língua(s) é que a criança usou nesta tarefa? (circule todas as linguas que foram faladas) Which languages did the child use in this task? (circle all answers that apply)

$$
\text { Português Crioulo Fula Mandinga Balanta Beafada }
$$

Outras (especificar) Others (please specify)

Muito obrigada, fizeste um bom trabalho. Agora podes regressar para a tua sala de aula /podes ir para casa.

Thank you, you did a good job. Now please return to your own classroom/you can go home.

Hora de fim da avaliação (Time of ending):

h m

Que língua(s) é que usou para administrar este teste? (circule todas as opções que se apliquem) Which language(s) did you use to apply this test? (circle all answers that apply)

Português Crioulo Fula Balanta Beafada Outras 